\title{
İlkokula Erken Yaşta Başlayan Öğrencilerin Okula Uyum Süreci ve Akademik Başarı Bağlamında Yaşadıkları Sorunlar
}

\author{
DOI: 10.26466/opus.529169 \\ * \\ Ali Özdemir* - Sifanur Battal**
* Dr. Öğrt. Üyesi, Marmara Üniversitesi, Eğitim Fakültesi, İstanbul / Türkiye ORCID: 0000-0001-6089-1966
** Y. L. Öğrencisi , Marmara Üniversitesi, İstanbul / Türkiye
ORCID: 0000-0003-4012-0253 \\ E-Posta: aliozdmr32@gmail.com \\ E-Posta: sifanurbattal@gmail.com
}

Öz

Millî Ĕ̆itim Bakanlı̆̆ı Illköğretim Kurumları Yönetmeliği 21/7/2012 tarih ve 28360 sayılı Resmi Gazetede yayınlanan genelge ile veli isteği doğrultusunda 60-66 aylık öğrencilerin ilköğretime kaydı yapılabilmektedir. Bu araştırmanın amact ilkokula veli isteği ile başlayan öğrencilerin (60-66 aylık) yaşadıkları uyum sorunları ile akademik başarılarının, veli ve öğretmen görüşlerine göre tespit edilip, değerlendirilmesidir. Araştırmada, nitel araştırma yöntemlerinden fenomenoloji deseni kullanılmıştır. Çalışma grubu, İstanbul ili Pendik ilçesinde sinıf öğretmeni olarak görev yapan 5 öğretmen ve bu öğretmenlerin sinıfinda erken yaşta okula başlayan 5 öğrenci velisinden oluşmaktadır. Verilerin toplanmasında yar yapılandırılmış görüşme formu kullanılmış, verilerin analizindede betimsel analiz yöntemi kullanılmıştır. Araştırmanın bulgularına göre ilkokula erken yaşta başlayan çocukların gelişim özelliklerine bağh olarak hazırbulunuşluk düzeylerinin yetersiz olduğu, çeşitli uyum sorunlar yaşadıkları ve buna bağlı olarak akademik başarılarının düşük olduğu sonuçlarına ulaşılmıştır. Illköğretim birinci sınıfa devam eden öğrencilerin gelişim özellikleri açısından benzer ay aralı̆̆ında olacak şekilde düzenlenmesi, okulöncesi eğitimin yayginlaştırılması ve ilköğretimde fiziksel aktivite derslerinin arttırılması gibi uygulamalar, yaşanan sorunların çözümünde katılımcılar tarafından önerilmiştir.

Anahtar Kelimeler: Okul sorunları, okula erken başlama, eğitim yönetimi 


\title{
Adaptation Process of Students Who Start Primary School at an Early Age and Their Problems on the Context of Academic Success
}

\begin{abstract}
Regulation on Primary Education Institutions of the Ministry of National Education With the circular published in the Official Gazette dated 21/7/2012 and numbered 28360, children between 60 and 66 months of age can be enrolled in primary school in line with the request of parents. The aim of this study is to determine and evaluate the academic achievement of the students who started with the request of parents (60-66 months) and their academic achievement according to the opinions of parents and teachers. In this study, a qualitative research method and phenomenological research design were used. The study group consisted of 5 teachers who work as primary school teachers in Pendik district of İstanbul and 5 parents who start school at an early age. Data were collected by semi-structured interview form, descriptive analysis method was used to analyze the data. According to the findings of the study, it has been concluded that due to the developmental characteristics of children starting early in primary school, the levels of readiness are inadequate, they experience various adaptation problems and their academic achievement is low. The applications of primary school first grade students in the same month range in terms of their developmental characteristics, the expansion of preschool education and the increase of physical activity courses in primary education are suggested by the participants in solving the problems.
\end{abstract}

Keywords: School problems, early school start, education management 


\section{Giriş}

Okula başlama, çocuğun ve ailenin yaşamında örgün eğitime ilk adım olması ve çocuğun psikomotor, sosyal, zihinsel ve duygusal uyum sağlaması açısından önemli bir süreçtir. Okula başlama, çocukluk çağında ortam değiştirmesi açısından zorludur. Bu değişiklik çocuğun gelecek hayatında başarılı olması için kritik bir öneme sahiptir (Seven, 2011). Çocuğun ilkokula başlama yaşı ise gelişim alanlarında ilkokula hazırbulunuşluk için gerekli yeterliliği sağlaması açısından tartışılan bir konudur. Piaget'in bilişsel gelişim kuramında işlem öncesi dönemde (2-7 yaş), çocuklar kuralların farkında değildirler ya da kurallara neden ihtiyaç olduğunu ve onlara neden uymak gerektiğini anlayamamaktadırlar. 7 yaşından itibaren başlayan somut işlemler döneminde ise çocuk ben merkezcilikten uzaklaşıp, parça ve bütün arasında sağlıklı ilişki kurabilmektedir. Ericson'un psikososyal gelişim kuramında 3-5 yaş dönemi çocukları girişkenliğe karşı suçluluk basamağındadırlar. Gerçek olan ve olmayanın farkını tam olarak anlayamazlar ve oyun en önemli uğraşılarıdır. 6-11 yaş dönemi çocukları ise başarıya karşı aşağılık basamağındadırlar. Bu yaştaki çocuklar, bilişsel gelişim açısından yeterli düzeye erişmemiş olup; başarısızlık durumunda, aşağılanma ve kendine güvensizlik gibi olumsuz duygular hissederler. Freud'un psikoseksüel gelişim kuramında 3-6 yaş dönemi çocukları fallik dönemde olup cinsel kimlik arayışında iken; 7-11 yaş latent (gizil) dönemdir. Gelişim kuramlarına bakıldığında, gelişim dönemlerinin 60 ay ile 72 ay ve üzerindeki çocuklarda farklılaştığ1 görülmektedir.

Türkiye'de 2012-2013 eğitim-öğretim yılında 4+4+4 eğitim sistemine geçilmesiyle birlikte Millî Eğitim Bakanlığı İlköğretim Kurumları Yönetmeliği resmi gazete yayınlanan 21/7/2012 tarih ve 28360 sayılı genelge ile veli isteği doğrultusunda $60-66$ ay arası çocukların ilkokula kaydı yapılabilmektedir (Milli Eğitim Bakanlı̆̆1 [MEB], 2012). Bu düzenlemeden önce, 31 Aralık tarihinde 72 aylık olan çocukların ilkokula kaydı yapılmaktaydı. Yeni düzenlemenin gerekçesi olarak, “... meslekî eğitimden arzu edilen düzeyde yararlanabilmek için, öğrencinin ilgi ve beceri alanlarının küçük yaşlardan itibaren tespit edilerek gerekli yöneltme ve yönlendirmelerin yapılması şarttır" gösterilmektedir (20.02.2012 tarih ve 2/358 sayılı 5.1.1961 tarihli ve 222 sayılı İlköğretim ve Eğitim Kanunu ile bazı kanun- 
larda değişiklik yapılmasına dair kanun). Ancak ilkokula kayıt yaşının düşürülmesi ve ilkokula başlamanın veli isteğine bırakılması gelişim dönemleri açısından ele alındı̆̆ında ilkokula hazır olmayan çocukların okula başlaması durumunu oluşturmuştur.

Dünya genelinde zorunlu eğitime başlama yaşı 3-7 yaş arasında değişmekte olup (Bayat, 2015); ilkokula erken yaşta kayıt yapılmasından önce, okul öncesi eğitime önem verdikleri bilinmektedir. Okuma öğretimine Avustralya, Lübnan, Uruguay ve İngiltere gibi ülkelerde 5 yaşında; Amerika Birleşik Devletleri, Portekiz, Norveç, Hollanda, İsviçre gibi ülkelerde 6 yaşında; İsveç, Danimarka gibi ülkelerde ise 7 yaşında başlamaktadır (Akyol, 2006; Güneş, 2000). Türk Tabipler Birliği (TTB)'nin yayınladı̆̆1 raporda "okul eğitimine katılabilmek için gerekli sosyal, duygusal, bilişsel, dil ve motor becerilerin gelişimi 6 yaştan (72 ay) önce tamamlanmadiğı; 5 yaş çocuğu (60-71 aylar arası) zihinsel, fiziksel, sosyal ve psikolojik olarak ilkokula henüz hazır olmadığı" belirtilmiştir (TTB, 2012).Havighurst (1972), ilkokulda kazanılması gereken temel becerilere en üst düzeyde ulaşabilmek için ilkokula başlamada gerekli olan okuma ve yazma hazırbulunuşluğunun sağlanması gerektiğini ve bu hazırbulunuşluğun en az 6,5 yaşında kazanılabileceğini belirtmiştir(Akt; Arı, 2014). Gray (1975)'e göre zeka yaşı 6 yaşın altında olan çocukların çoğu okumayı öğrenmekte ancak zeka yaşı 6-6,5 olanların bu konuda daha iyi gelişim gösterdikleri belirlenmiştir (Akt; Çelenk, 2006). ODTÜ Eğitim Fakültesi konuyla ilgili; çocuğun hafızasını öğrenme için etkin kullanması, mantıksal düşünmesi, yorum yapması, bir işi baştan sona bitirebilme becerilerisi için 6 yıl geçmesi gerektiği, 6 yaşından önce beyindeki bilişsel yapının okul temelli akademik öğrenme için gelişmiş olmadığ1 yönünde görüş bildirmiştir(Kartal, 2013). Yapılan çalışmalarda gerekli olgunluğa erişilmiş olması bakımından okula başlama için en uygun yaşın 5.9 ile 6.3 yaşlar arasında olduğu belirtilmiştir (Sharp, 1998, Akt; Ülkü, 2007). Harris ve Sipay (1986)'e göre ise, takvim yaşı hızlı değişmeleri içermesi nedeniyle önemli ancak tek başına yeterli değildir(Akt; Tutal ve Oral, 2015). Okula başlama veya başlamama konusunda takvim yaşı önemli olmakla birlikte, çocukların psikomotor, bilişsel, sosyal ve duygusal gelişim düzeyleri ve davranış gelişimi açısından hazırbulunuşlukları da önemlidir (Aykaç vd., 2014; Calp, 2014; Denham 2006; Howes vd., 2008; Snow 2006). Okul için gerekli becerilerin yerine 
getirilebilmesi için çocukların bilişsel,fiziksel, duygusal ve sosyal açıdan olgunlaşması gerekmektedir. Olgunlaşma, öğrenme geçmişinden ayrı olarak, vücuttaki organların kendilerinden beklenen işlevi yapabilecek seviyeye erişebilmesi için, genetik faktörlerle meydana gelen biyolojik bir değişimdir (Senemoğlu, 2012). Olgunlaşma, çevresel faktörlere bağlı olmayıp kalıtımın etkisiyle gerçekleşir (Kahramanoğlu vd., 2014). Örneğin ince motor becerin gelişimi olgunlaşmayla alakalı bir durumdur ve genel olarak takvim yaşıyla orantılıdır. Olgunlaşma ve öğrenme sonucu kişinin bir davranışı gerçekleştirebilecek seviyede bulunması (Erden ve Akman, 2004), bir öğrenme için gereken hazırlık davranışları edinmesi, sinir sisteminin öğrenmeye hazır halde olması olarak tanımlanan hazırbulunuşluk kavramını; araştırmacılar, çocukların belirli bir büyüme düzeyine erişmelerinin, okula başlamak için mecburi bir ön şartı olduğunu ifade etmişlerdir (Çataloluk, 1995 akt; Canbulat, 2017). Hazırbulunuşluk, yaşa bağlı olarak çocuğun büyümesi, gelişmesi ve genetik faktörlerden etkilediği gibi çocuğun sosyo-kültürel çevresi ve öğrenme yaşantılarından da etkilenmektedir (Bayat, 2015). Gowani ve Merali (2007), Kagan (1995) ve UNICEF (2012)'e göre, hazırbulunuşluk, okulun çocuğa, çocuğun okula ve aile ile çevrenin de çocuğun okula başlamasına hazır olmasıdır (Akt; Boz ve Yıldırım, 2014).Yeterince hazır olmadan okula gönderilen çocuklarda çok kere başarısızlık gözlemlenmekte (Kutluca vd., 2014) ve bu durum çocuğu duygusal anlamda da yıpratmaktadır (Erkan ve Kırca, 2010).Oktay (1982)'a göre ilk yılda ciddi bir soruna rastlamasa da daha ileriki yıllarda okul ve okuma ile ilgili bazı olumsuz tutum ve tavır gösterebilir (Akt; Kutluca vd., 2014). ODTÜ Eğitim Fakültesi 40 dakikalık ders süresi boyunca dikkat süresi kısa olan 6 yaş öncesi çocuğun oturması ve dikkatini derse yoğunlaştırmasının güç olduğunu; bu çocukların dikkat, disiplin ve dinleme sorunları yaşadığını ve bu şekilde etiketlemelerin gelecekteki eğitim hayatlarında derin izler bırakacağını belirtmiştir (Kartal, 2013). Çelenk (2001), okuma yazma için gelişimsel olarak hazır bulunmayan çocukların zorlanması durumunda, okuma yazmaya karşı, hatta tüm öğretim etkinliklerine karşı olumsuz tavır geliştirebileceğini ifade etmiştir. Okula kolay uyum sağlayan, başarılı olan ve daha az problem davranış gösteren çocuklar, psikolojik ve gelişim özellikleri açısından ilkokul birinci sınıf eğitimi için gerekli hazırbulunuşlukta olanlardır (Chan, 2012; Entwisle ve Alexander, 
1998 akt; Boz ve Yıldırım, 2014). Örneğin çocuğun bilişsel açıdan gerekli olgunlukta olması; yeni fikirler üretmesi ve yeni deneyimler yaşaması açısından okula daha rahat uyum sağlamasında (Yörükoğlu, 2010), dil gelişiminin geride olması sosyal uyumsuzluk, okuma zorluğu ve çeşitli sorunlar yaşamasında etkili olmaktadır (Sevinç, 2005). Çocuklarda, gelişim dönemlerindeki doğal zorluklara karşı geliştirilen tepkiyi içeren duygusal düzeydeki bozukluklar, uyum bozuklukları olarak adlandırılmaktadır (Yavuzer, 2012). Uyum bozuklukları içsel çatışmaların davranışlara yansıması sonucu çeşitli nedenlerle ortaya çıkar. Sürekli hırçınlık, sinirlilik, geçimsizlik, kavgacılık, okuldan kaçma, çalma, yangın çıkarma, sürekli başkaldırma ve kuralları çiğneme gibi davranışlar uyum bozukluklarının belirtileridir (Yörükoğlu, 2010). Oğuzhan (1981)'a göre uyumsuz çocuklar saldırgan, suça eğilimi olan veya suç işleyen duygusal durumu bozuk çocuklar olarak tanımlamaktadır (Akt; Selimhocalığlu, 2009). Kaya ve arkadaşları (2006) ise kekemelik, gece işemesi ve tırnak yeme gibi sorunları ruhsal uyum bozuklukları kapsamında değerlendirmişlerdir. Genel anlamda uyum, çocuğun içinde bulunduğu çevre ile kendi özellikleri, benliği arasında dengeli bir ilişki kurması ve sürdürebilmesidir (Doğan vd., 2008). Öğrenme öğretme sisteminin önemli bir girdisi olan okul uyumu ise çocuğun ilk defa girdiği çevrenin beklentilerine yönelik olarak sergilediği sosyal, davranışsal ve akademik tepkilerine bağlı olarak çocukların okul ortamındaki başarı, ilgi ve rahatlık düzeylerini içeren geniş kapsamlı bir terimdir (Canbulat, 2017). Okula başlama ile çocukların yaşamı boyunca etkisi sürecek bir uyum dönemi başlar. Okula başlayan çocuk, yeni statüsündeki değişimlere, yeni çevreye, sosyal yaşantılara ve farklı kültürlere uyum sağlamak durumundadır (Fabian, 2000). Bu sürecin başarılı bir şekilde atlatılması için çocukların farklı gelişim alanlardaki becerileri açısından ilkokula başlama seviyesine ulaşmış olması gerekmektedir.Milli Eğitim Bakanlığı tarafından okula başlamada takvim yaşı baz alınarak yapılan düzenlemeler, ilkokula hazır oluşu etkileyen; fizyolojik, zihinsel, soyalduygusal ve çevresel (Oktay, 2010) faktörlerin göz ardı edilerek çeşitli uyum sorunlarına ve akademik anlamda başarısızlığa zemin hazırladığını düşündürmektedir.

Araştırma 2012-2013 eğitim-öğretim yılında yürürlüğe giren, veli isteğiyle erken yaşta okula başlatılan öğrencilerin yaşadıkları uyum so- 
runlarının ve akademik başarılarının farklı alt boyutlarda incelenmesi açısından önemlidir. Araştırma ile erken yaşta okula başlayan ve halen ilkokul düzeyinde eğitimine devam etmekte olan öğrencilerin; okulda ve evde gelişim özelliklerinden dolayı yaşadıkları problemler, hazır bulunuşluk düzeylerinin öğrenme süreçlerine ve akademik başarılarına etkisi tespit edilip, değerlendirilmiştir. Araştırmadan elde edilen bulgular, okula başlama yaşının düşürülmesinin yol açtığı uyum sorunlarına ilişkin var olan durumun belirlenerek sürecin iyileştirilmesi ve politika yapıcılara çözüm önerileri sunması açısından önemlidir. İlgili alanyazın taramalarında ilkokula erken yaşta başlama ile ilgili öğretmen görüşlerinin alındığı çalışmalara rastlanmış (Arı, 2014; Aybek ve Aslan, 2015; Aykaç vd.,2014; Bayat, 2015; Boz ve Yıldırım, 2014; Calp, 2014; Canbulat, ve Yıldızbaş, 2014; Cerit vd., 2014; Dinç vd., 2014; Doğan vd.,2014; Gündüz ve Özarslan, 2017; Koçyiğit ve Saban, 2014; Kutluca vd., 2014; Külekçi, 2013; Merter vd., 2014; Ogelman vd., 2015; Özenç ve Çekirdekçi,2013; Öztürk, 2013;Polat vd., 2014; Sağlam ve Besen, 2015; Şentürk, 2016; Uzun ve Alat, 2014; Ünal-Peker, 2013); ancak veliler ile ilgili yapılan bir çalışmaya rastlanmamıştır. Bu bağlamda erken yaşta okula başlayan çocukların gelişim özellikleri dikkate alınarak sadece okul ortamında değil ev ortamında da yaşadığı sorunların tespit edilip değerlendirmesi açısından araştırmanın geleceğe ışık tutacağı düşünülmektedir.

$\mathrm{Bu}$ bağlamda araştırmanın amacl, ilkokula veli isteği ile başlayan öğrencilerin (60-66 ay) yaşadıkları uyum sorunları ile akademik başarılarının, veli ve öğretmen görüşlerine göre değerlendirilmesi ve politika yapıcılara öneriler üretebilecek somut tespitlerde bulunabilmektir.Bu genel amaç doğrultusunda şu alt problemlere cevap aranmıştır:

1. İlkokula erken yaşta başlama uygulamasına ilişkin öğretmen ve veli görüşleri nelerdir?

2. İlkokula erken yaşta başlayan öğrencilerin gelişim özelliklerine ilişkin öğretmen ve veli görüşleri nelerdir?

3. İlkokula erken yaşta başlayan öğrencilerin okula uyum sürecine ilişkin öğretmen ve veli görüşleri nelerdir?

4. İlkokula erken yaşta başlayan öğrencilerin akademik başarılarına ilişkin öğretmen ve veli görüşleri nelerdir? 
5. İlkokula erken yaşta başlayan öğrencilerin ilkokula hazır bulunuşluğuna ilişkin öğretmen ve veli görüşleri nelerdir?

6. İlkokula erken yaşta başlayan öğrencilerde görülen sorunlarla baş etmede kullanılan yöntemlere ilişkin öğretmen ve veli görüşleri nelerdir?

7. İlkokula erken yaşta başlayan öğrencilerde görülen mevcut sorunlara yönelik çözümler ile ilgili veli ve öğretmenlerin görüşleri nelerdir?

\section{Yöntem}

Çalışmanın bu bölümünde; araştırma deseninden, çalışma grubundan, veri toplama aracindan, verilerin toplanmasından ve verilerin analizden bahsedilmektedir.

\section{Araştırma Deseni}

Araştırmada nitel araştırma yöntemi kullanılmıştır. Araştırmada nitel araştırma desenlerinden fenomonoloji/olgubilim araştırma deseni kullanılmıştır. Olgubilim deseni farkında olduğumuz ancak derinlemesine ve ayrıntılı bir bilgiye sahip olmadığımız olgulara odaklanmaktadır (Yıldırım ve Şimşek, 2013). Bu desende farkında olunan ancak ayrıntılı bilgiye sahip olunmayan olgulara odaklanilır (Creswell, 2015). Bu kapsamda bu olguya yönelik bireylerin yaşantılarının anlamı, yapısı ve özü incelenir. Diğer bir deyişle insanların ilgili olguları nasıl deneyimledikleri metodolojik, özenli ve derinlemesine betimlenmeye çalışılır (Patton, 2014). Bu bağlamda araştırma öğretmenlerin ve velilerin erken yaşta ilkokula başlayan çocuklardaki akademik başarı ve uyum sorunlarına ilişkin farkında oldukları fakat derinlemesine bir anlayışa sahip olmadıkları görüşlerin tespit edilmesini sağlamıştır.

\section{Katılımcilar}

Araştırmada, katılımcılar farklı ilkokullarda görev yapan öğretmenler ve bu okullarda öğrenim gören ilkokula erken yaşta başlayan öğrenci velilerinden seçilmiştir. Katılımcıların seçiminde amaçlı örneklem yönt- 
emi kullanılmıştır. Amaçlı örneklem kapsamında ilgili araştırma çerçevesinde belirli bir amaca hizmet eden farklı örnekleme yöntemleri vardır. Bu kapsamda önceden belirlenmiş bazı önemli ölçütleri karşılayan ölçüt örneklem bu yöntemlerden birisidir (Patton, 2014). Katılımcılar, 2017-2018 eğitim öğretim yılında ilkokul kademesinde sınıf öğretmenliği yapması, sınıfında ilkokula erken yaşta başlayan öğrencilerin bulunması ve ilkokula kayıt yaşının düşürülmesi değişikliğinden önceki dönemde çalışmış olması ölçütlerini sağlayan İstanbul ili Pendik ilçesindeki gönüllü öğretmenlerden ve bu öğretmenlerin görev yaptıkları okullarda erken yaşta okula başlayan öğrencilerin velilerinden seçilmiştir. Bununla birlikte öğretmenlerin kıdem yılı ve okuttuğu sınıf kademesi ile velilerin öğrenim durumları dikkate alınmıştır. Okuldan, velilerden ve öğretmenlerden kaynaklanan bir takım nedenlerle katılımcıların cinsiyeti dengelenememiş; 10 kadın olmak üzere toplam 5 öğretmen ve 5 veli araştırmaya gönüllü olarak katılmıştır. Katılımcıların kimliklerini korumak için kendilerine ve okullara rumuzlar verilmiştir. Ö1 - Ö5 arası rumuzlar öğretmenlere, V1 - V5 arası rumuzlar ise velilere verilmiştir. Katılımcıların demografik bilgileri Tablo 1'de verilmiştir.

Tablo 1. Katılımcılarn Demografik Bilgileri

\begin{tabular}{|c|c|c|c|c|c|c|c|}
\hline $\bar{z}$ & 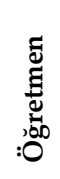 & 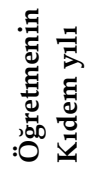 & 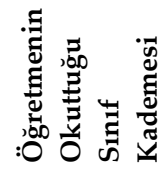 & $\stackrel{\overline{0}}{>}$ & 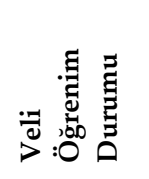 & 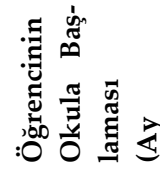 & 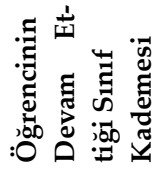 \\
\hline A İlkokulu & Ö1 & 16 & 3 & V1 & Üniversite & 60 & 3 \\
\hline A İlkokulu & Ö2 & 7 & 4 & $\mathrm{~V} 2$ & İlkokul & 66 & 1 \\
\hline A İlkokulu & Ö3 & 21 & 1 & V3 & İlkokul & 65 & 1 \\
\hline B İlkokulu & Ö4 & 7 & 1 & V4 & İlkokul & 66 & 1 \\
\hline C İlkokulu & Ö5 & 17 & 2 & V5 & Lise & 60 & 2 \\
\hline
\end{tabular}

\section{Verilerin Toplanması}

Nitel araştırmalarda katılımcıların özellikleri ve olgunun niteliği veri toplanmasında yöntemin belirlenmesini sağlar. Ancak veri toplama sürecinde araştırmacının temel amacı, katılımcıların olguya yönelik yaşantılarını ve algılarını daha iyi yansıtarak yapılandırmaktır (Ersoy, 2016). Bu doğrultuda araştırmanın verileri 2017-2018 eğitim öğretim 
yılında, İstanbul ili Pendik ilçesinde kamu okullarında görev yapan gönüllü sınıf öğretmenleri ve bu okullara devam etmekte olan öğrenci velilerinden toplanmıştır. Katılımcıların sözlü ve yazılı onayı alınarak, gönüllük ilkesi kapsamında kendilerine uygun bir zamaan diliminde görüşmeler yapılmıştır. Katılımcılara araştırma ile ilgili bilgi verilmiş ve görüşmeler, katılımcıların kendilerini rahat ifade edebilecekleri ortamlarda, yaklaşık 20-30 dakika sürede yüzyüze yapılmıştır. Araştırmada kullanılan görüşme formu iki kısımdan oluşmuştur: kişisel bilgi formu ve konu odağını iyi yansıtabilmek açısından araştırmacılar tarafından geliştirilen yarı yapılandırılmış görüşme formudur. Görüşme formu hazırlanmadan once alanyazın taraması yapılmış; yurt içi ve yurt dışında yapılan araştırmalar, ilkokul programındaki kazanımlar, 4+4+4 eğitim sistemine ilişkin mevzuat, Milli Eğitim Şuraları ve Raporlar çalışmanın kuramsal kısmını oluşturmuştur. Bu çerçevede oluşturulan sorular, öğretmen ve velilerin ilkokula erken yaşta başlayan öğrencilerin gelişim özellikleri, ilkokula hazır bulunuşlukları, akademik başarıları ve yaşadıklarını düşündükleri uyum sorunları ile bu sorunlarla baş etmede kullandıkları yöntemler ve paylaşımda bulunma konuları hakkında bilgi almayı amaçlamıştır. Görüşme soruları geliştirilirken konu üzerinde uzman öğretim elemanlarının görüşleri alınarak son hali verilmiştir. Görüşmeler esnasında öngörülemeyen alanlara yönelik bazı yedek sorular, soruların anlaşılamadığı durumlarda ya da yeterli yanıt alınamadığı durumlar için kullanılmıştır. Katılımcıların çoğu görüşmenin ses kayıt cihazına kayıt edilmesine izin vermiş ve görüşmeler kayıt altına alınmıştır. Sadece bir katılımcı ses kayıt cihazı kullanılmasına izin vermemiş ve görüşme yazılı olarak kayıt altına alınmıştır.

\section{Verilerin Analizi}

Araştırmada elde edilen verilerin analizinde betimsel analiz tekniği kullanılmıştır. Betimsel analiz tekniğine göre analiz edilen bilgiler, önceden belirlenen temalara göre düzenlenir ve yorumlanır (Yıldırım ve Şimşek, 2013). Bu analiz türünde temel amaç elde edilmiş olan bulguların okuyucuya özetlenmiş ve yorumlanmış bir biçimde sunulmasıdır (Yıldırım ve Şimşek, 2013). Veriler analiz edilmeden önce görüşmeye ilişkin ses kayıtları yazıya dökülmüştür. Yapılan dökümlerin 
doğruluğunun kontrolü ve geçerli olması açısından ses kayıtları tekrar dinlenmiş ve kontrol edilmiştir. Betimsel analiz dört aşamada gerçekleşmektedir (Yıldırım ve Şimşek, 2013). Birinci aşamada araştırma sorularında, kavramsal çerçevede ve görüşmelerde yer alan boyutlardan hareket ederek veri analizi için bir çerçeve oluşturulmuştur. Araştırmada kullanılan sorular; gelişim özellikleri, okula uyum, akademik başarı ve hazırbulunuşluk kavramları düşünülerek hazırlanmıştır. Görüşme formunda yer alan sorular katılımcıların ilkokula erken yaşta başlayan öğrenciler hakkındaki bilgi durumları; öğrencilerin gelişim özellikleri, okula uyum, akademik başarı ve hazırbulunuşluk temaları olarak, uygulamaları ise; katılımcıların yaşadıkları sorunlarla baş etmede kullanılan yöntemler ve mevcut sorunların çözümü temaları olarak belirlenmiştir. Analizin ikinci aşamasında oluşturulan çerçeveye dayalı olarak veriler anlamlı ve mantıklı bir biçimde bir araya getirilerek düzenlenir (Yıldırım ve Şimşek, 2013). Araştırma kapsamında oluşturulan temalara dayalı olarak veriler okunmuş ve araştırmacı tarafından geliştirilen veri toplama formlarına not edilmiştir. Veri toplama formları incelenerek birbirine benzer görüşler tespit edilerek düzenlenmiştir. Bir soruya birden fazla görüş belirten katılımcıların bütün görüşleri ayrı ayrı analiz edilmiştir. Bu kapsamda gelişim özelliklerine ilişkin ilkokula erken yaşta başlayan öğrencilerin evde zorlandığı gelişim alanları ve öğretmenlerin farklı gelişim alanlarına ilişkin görüşleri, okula uyum ile ilgili evde ve okulda, alanyazında uyum sorunu olarak tanımlanan davranışlara ilişkin görüşleri, akademik başarı kapsamında ilkokul eğitim programı kazanımları ve değerlendirme sürecine ilişkin görüşleri, hazırbulunuşluk kapsamında ilkokul eğitim programının gerektirdiği öğrenmeyi kazanabileceği hazırlık davramışlarına ilişkin görüşleri ve uyum sorunları ile baş etmede kullanılan yöntem ve uygulamaları, ilgili temalar altında listelenmiştir. $\mathrm{Bu}$ aşamadan sonra görüşler, onu tanımlayan kavramlarla ilişkilendirilmiştir. Bu kavramlar çalışmanın kuramsal kısmından yararlanılarak yapılmış ve gerekli yerlerde doğrudan alıntılarla desteklenmiştir. Analiz sürecinin sonunda tanımlanan bulgular açıklanmış, ilişkilendirilmiş, anlamlandırılmıştır ve betimlemelerden yola çıkılarak yorumlar yapılmıştır. Bu kapsamda ilkokula erken yaşta başlayan çocukların gelişim özellikleri temasında elde edilen verilerin hazırbulunuşluk, uyum süreci ve akademik başarı temalarındaki ver- 
ilerle ilişkisi; öğretmenlerin kıdem yılı, velilerin öğrenim durumu gibi değişkenlerin, elde edilen bulgular kapsamında değerlendirilmesi yapılmıştır. Betimsel analiz tekniğinde görüşülen bireylerin görüşlerini çarpıcı bir şekilde yansıtmak amacıyla doğrudan alıntılara sıkça yer verilir (Yıldırım ve Şimşek, 2013). Araştırmanın güvenirliğini sağlamak için bu araştırmada, elde edilen veriler farklı araştırmacılar tarafından ayrı ayrı ve bireysel olarak kodlanmış ve analiz edilmiştir. Bu analizler karşılaştırılarak ortak bir karara varılmıştır. Araştırmanın geçerliğini sağlamak için her aşamada uzman görüşüne başvurulmuştur. Araştırmanın geçerlik ve güvenirliğini arttırmak amacıyla katılımcıların görüşlerini ortaya çıaran alıntılara sıklıkla yer verilmiştir.

\section{Bulgular}

Bulgular, araştırmanın amacı doğrultusunda cevap aranan sorular çerçevesinde incelenmiştir. Bu doğrultuda katılımcıların görüşleri ilkokula erken yaşta başlama uygulaması, ilkokula erken yaşta başlayan öğrencilerin; gelişim özellikleri, uyum süreci, akademik başarıları, hazırbulunuşluk düzeyleri ile ilkokula erken yaşta başlayan öğrencilerde görülen sorunlarla baş etmede kullanılan yöntemler ve çözüm önerileri olmak üzere 7 genel tema etrafında toplanmıştır.

\section{İlkokula Erken Yaşta Başlama Uygulamasına İlişkin Bulgular}

Araştırmada çocukların ilkokula erken yaşta başlamasına ilişkin görüşlerin nasıl olduğunu saptamak amacıyla öğretmenlere ve velilere "Illkokula erken yaşta başlamanın olumlu ve olumsuz yönleri nelerdir?" sorusu yöneltilmiştir. Ayrıca öğretmenlere "Sınfınızdaki öğrenciler ay olarak birbirinden ne kadar farklıdır? Farklı yaş grubundaki öğrencilerle bir arada çalışma öğrenme sürecini nasıl etkiledi?" soruları yöneltilmiştir. Bu sorulara verilen cevapların analiz edilmesiyle ortaya çıkan sonuçlar Tablo 2'de verilmiştir. 
Tablo 2. İlkokula Erken Yaşta Başlama Uygulamasına İlişkin Bulgular

\begin{tabular}{llr}
\hline Görüşler & f & Katılımcılar \\
\hline İlkokula erken yaşta başlamak olumludur & 1 & V3 \\
İlkokula erken yaşta başlamak olumsuzdur & 9 & Ö1,Ö2,Ö3,Ö4,Ö5,V1,V2,V4,V5 \\
Kurallara uymada zorluk, sorumluluk bilinci yok & 4 & Ö1,Ö2,Ö4,V1 \\
Anneyi özlüyor & 4 & Ö2,Ö3,Ö5,V3 \\
Yazmada zorluk yaşıyor & 5 & Ö3,Ö4,V1,V2,V3 \\
Okumada zorluk yaşıyor & 1 & Ö1,Ö4,Ö5,V4 \\
Aklı hep oyunda & 4 & Ö1,Ö2,Ö3,Ö4,V5 \\
Sinıftan geri, başarısız & 5 & Ö1,Ö4 \\
Geri kalınca üzülüyor, ağlıyor & 2 & Ö3,Ö4,Ö5,V1 \\
Okuldan sıkıllyor & 4 & Ö3,Ö4 \\
Paylaşmayı sevmiyor & 2 & V2,V5 \\
Arkadaşlık kurmada zorluk yaşıyor & 2 & Ö1,Ö3,Ö4,Ö5 \\
Sinıfta çocuklar arasında seviye farkı var & 4 &
\end{tabular}

Tablo 2'de yer alan bulgular değerlendirildiğinde katılımcıların tamamına yakını $(f=9)$ ilkokula erken yaşta başlamayı olumsuz bulmuşlardır. Katılımcılar tarafından en sık tekrar eden veri yazmada zorluk ve sınıftan geri kaldığı $(f=5)$ yönünde olmuştur. Bu doğrultuda Ö4 "Olumsuz yönleri birçok yerde fark ediliyor, yazmada zorlanıorlar. Bir tane öğrencim hiç zorluk yaşamadı ama verilen ödevi yerine getirmede sorumlulukların bilme de diğer çocuklardan çok bariz farklı olduğu belli oluyor çünkü oyun istiyordu. Bundan başka olumsuz yönleri de arkadaşlarnndan hep geride kalıyorlar, dönem dönem öğrencilerimiz öne geçer geri kalır ancak daha önce de 1. sını okuttum, erken yaşta başlayan geriden geliyor ve hiçbir zaman öne geçemediler yani oyunda bile dersi geçiyorum oyunlarda geri kaldılar. Yani birinciliği hiç tadamadılar." ifadesini kullanarak erken yaşta başlayan çocuğun yazmada zorluk çektiği, sorumluluk alamadığı ve sinıftan hep geri kaldığ1 için başarısız olduğunu belirtmiştir. Benzer şekilde Ö2 "...Okuma yazmayı öğrenebiliyor ama erken başladığı için diğger sinıf arkadaşlarından hep daha geride oluyor olumlu bir yanı olmuyor açıkçası."

Sınıftan geri ve başarısız olması ile ilgili kurallara uymada ve sorumluluk almada zorluk, anneyi özleme, aklının hep oyunda olması ve sıkılmasını Ö1 “Olumlu göremedim, küçük yaşta başladığı için çocuğun aklı hep oyunda. Okuma yazmayı her türlü öğreniyor fakat derslere karşı isteksiz oluyor görev bilinci tamamen oturmamış kurallara uyumda zorluk yaşıyor. El kasları gelişmediği için yapması gerekenler de yeterli olamıyor. Böylece başarısızlı̆̆ı tadıyor mutsuz oluyor", Ö3 "Ben daha çok olumsuz yönle- 
rini yaşadım. Benim sinıfimda da iki üç tane küçük öğrenci vardı, okula ilk başlarda hevesle geldiler ama daha sonra dersler yoğunlaştıkça çizgi çalışmaları olsun ses verme olsun çok zorlandilar, yazmak istemediler, yoruldular, sıkıldılar, ailelerini özlediler, gitmek istediler sürekli, yani sınıfa uyum sağlayamadılar", Ö5 "Bence olumlu sonuçları olmuyor, erken başlamamal. Okul öncesine başlaması lazım okuma yazma çalışmalarına erken yaşta başlamalı. 66 aylıklar onun altındaki çocuklar anneden ayrilmada zorlanıyorlar. 6 ders saatinde okulda kalmakta zorlanıyorlar, 4 dersten sonra çocuk sormaya başlıyor: Annem ne zaman gelecek?, ne zaman anneme gideceğim? küçük başlayanların hepsinde ben bu durumu yaşadım" şeklinde ifade etmişlerdir.

Öğretmenlerin tamamı erken yaşta okula başlamayı olumsuz değerlendirmektedir. Benzer şekilde velilerin çoğu $(f=4)$ erken yaşta okula başlamanın olumsuz yönlerine dikkat çekmiştir. Bununla ilgili olarak V2 "Olumlu değil, çocuk zorluk çekiyor; hem ödevlerinde hem okuldaki arkadaşlarıla ona çok zor oluyor. Arkadaşlarıyla yaşıt değiller, onlar 1 yaş ondan büyü k" ifadesiyle sosyal açıdan da olumsuz olduğunu belirtmiştir. V4 ise "olumlu yönünü bilmiyorum, olumsuz yönü ilk zamanlar çok sıkıntı çektik. Hep oyun oynamak istedi, öğretmenimiz de bundan şikayet etti. İlk dönem bayağı bir sıkıntı yaşadık..." ifadesiyle, çocuğun aklının hep oyunda kaldığını belirtmiştir. Katılımcılardan V1 ve V5 ise çocuğu okula erken yollamayı kendi hataları olarak değerlendirmekte bunu şu şekilde ifade etmektedirler: V1 "...çok zorlandık, el becerileri, görevleri yetişme konusunda, okula istek konularında sıkıntı yaşadık. Hiç olumlu gelmedi, pişmanım 3 ay bile çok şey fark ettirdi." V5 "Kendinden büyük yaşlı çocuklar olduğu için Arda pimi çekilmiş bomba gibiydi, çok hırçın bir çocuk oldu keşke böyle olmasaydl, keşke yaşında gitseydi."

Katılımcılardan V3 ilkokula erken başlamayı olumlu olarak değerlendirmiş ancak sıkıntı yaşadığını da şu şekilde belirtmiştir: "Erken yaşta okula başlaması iyi, olumsuz bir yönünü görmedim açıķası. Olumlu yönü daha fazla bence. Evde şimdi tek başına olduğu için sıkılıyor, ablası okula gidiyor heves ediyor; ablasının kitabın alıyor, böyle test çözüyor, çözmeye çalışıyor, kendi kafasından oyun yapıyor falan çok hoşuna gidiyordu. Okula gidip de kendi testini çözmek şu an hoşuna gidiyor. İlk zamanlarda öğrenemiyor gibi kendine sıkıntı yaptı, biraz üzerinde durdum, bayağı bir durdum üzerimde ama öğrenmeye başladığın hissettiği anda hoşuna gitmeye başladı. Çok güzel 
gittik yani bir sıkıntı yaşamadık. Okumakta biraz sıkıntı yaşadı, yazmakta da zorlandr."

Öğretmenler, yapılan görüşmelerde öğrenciler arasında 8 aydan 24 aya kadar değişen ay farkı olduğunu ve öğrenme sürecine olumsuz etkiler yaptığını şu şekilde ifade etmişlerdir: Ö3 “En küçük ve en büyük arasında 2 yıl var maalesef. Öğrenme süreci çok zor oluyor. Kimi önden gidiyor, yaptyor her şeyi 5 dakikada bitiriyor; kimi bir ders boyunca 2 ders boyunca yapamyor. Sinffta hani uçurum oluyor seviye olarak.", Ö5 "60 aylık da vardı 82 aylık da. Arada uçurum vardı. Çocukların olgunluk seviyesi arasında da uçurum vardı. Sosyal ve duygusal açıdan onlardan çok gerideydi ve sürekli olarak ne zaman hamuru oynayacağım?, ne zaman oyun oynayacă̆ım?, ne zaman zil çalacak?, bahçeye ne zaman gideceğiz? Yani oyun çağı çocu ğuydu o küçük yaş grubu akademik faaliyetlerden çok kolay sıkılıyor, daha çok oyun oynamak istiyor.", Ö1 "60 ve 72 aylık çocuklar vardı. Başarll olan hızl ilerlerken beklemekten sıkılıyor. Erken başlayan bu hıza yetişemiyor ve sınıf düzenini disiplini bozuyor. 60 aylıklar geride kaldığını hissedince üzülüyor", Ö4 "8 ay fark vardı. Bana sıkıntı yaşattı. Çocuk okuyamadı, geriden geldi, biraz panikledi, biraz korktu. Geri kaldığı için üzüldü, ă̆ladl, okula gelmek istemedi, karnı ağrıdı. Bunların hepsinin dersten dolayı olduğunu düşünüyorum etkilendi."

\section{İlkokula Erken Yaşta Başlayan Öğrencilerin Gelişim Özelliklerine İlişkin Bulgular}

Araştırmada ilkokula erken yaşta başlayan öğrencilerin farklı gelişim alanlarına ilişkin görüşlerin nasıl olduğunu saptamak amacıyla öğretmenlere "Illkokula erken yaşta başlayan öğrencilerin gelişim düzeyleri nasıldır? Psikomotor, bilişsel ve sosyal duygusal gelişim düzeyine göre öğrenme sürecinde yaşadığınız zorluklar var mıydı?"; velilere "Çocuğunuzun erken yaşta ilkokula başlamasından dolayı, öğretim süreciyle ilgili evde zorlandı̆̆ını oldu mu?" soruları yöneltilmiştir. Bu soruya verilen cevapların analiz edilmesiyle ortaya çıkan sonuçlar Tablo 3'te verilmiştir.

Tablo 3'te yer alan bulgular değerlendirildiğinde öğretmenlerin tamamı psikomotor alanda ve sosyal duygusal alanda sıkıntı yaşadıklarını belirtmişlerdir. 
Tablo 3. Illkokula Erken Yaşta Başlayan Öğrencilerin Gelişim Özelliklerine İlişkin Bulgular

\begin{tabular}{|c|c|c|c|}
\hline $\begin{array}{l}\text { Gelişim } \\
\text { Alanları }\end{array}$ & Görüşler & $\mathrm{f}$ & Katılımcılar \\
\hline \multirow{4}{*}{$\begin{array}{l}\text { Psikomotor } \\
\text { Alan }\end{array}$} & El kasları gelişmemiş & 8 & Ö1,Ö2,Ö3,Ö4,Ö5,V1,V3,V5 \\
\hline & Kaba motor becerilerinde sıkıntı yok & 2 & Ö2,Ö4 \\
\hline & Kaba motor & & \\
\hline & becerilerde geri & 1 & Ö1 \\
\hline \multirow{3}{*}{ Bilişsel Alan } & Okuyamıyor,anlayamıyor & 2 & Ö4,V5 \\
\hline & Okuyor, anlayamiyor & 2 & Ö3,V2 \\
\hline & Anliyor, yapamiyor & 4 & Ö1,Ö2,Ö5,V3 \\
\hline \multirow{10}{*}{$\begin{array}{l}\text { Sosyal } \\
\text { Duygusal } \\
\text { Alan }\end{array}$} & Çabuk küsüyor & 3 & Ö1,Ö2,Ö5 \\
\hline & Kendini ifade edemiyor & 2 & Ö2,V2 \\
\hline & Çekingen, içe kapanik & 3 & Ö2,Ö4,Ö5 \\
\hline & Arkadaşlık kurmada sıkıntı yaşıyor & 4 & Ö1,Ö5,V2,V5 \\
\hline & Anne babaya bağlı & & \\
\hline & Ağlıyor,üzülüyorTemizlik & 3 & Ö3,Ö4,Ö5 \\
\hline & düşük düzeyde & 3 & Ö2,Ö3,Ö4 \\
\hline & Sınıf düzenine uyum sağlayamıyor & 1 & Ö2 \\
\hline & Uyum problemleri yaşıyor & 2 & Ö1,Ö3 \\
\hline & & 7 & Ö1,Ö2,Ö3,Ö4,Ö5,V1,V5 \\
\hline
\end{tabular}

Katılımcılar tarafından en sık tekrar eden veri el kasları gelişmemiş olmuştur. Bununla ilgili olarak Ö1 "Yeterince gelişmemiş, kesme yapıştırmada yeterli olamıyorlar, koşma beden eğitimi oyun gibi aktivitelerde de geri kalıyorlar." görüşüyle kaba motor becerilerde de geri olduklarını ifade etmiştir. Buna karşıt olarak Ö2 "Psikomotor gelişimde mesela makasla kesme çalışmalarında hep geride kalıyorlardı. Resmin ortasindan kesiyorlardı, yapamıyorlardı, tutamıyorlardı; makası çocuk masası olmasına rağmen tutamıyordu. Mesela boyama yaptırdığımda hep şaşırarak ya da karalayarak yapıyordu. Büyük kas gelişiminde bir sıkıntı yoktu, onlar da iyiydi. Çünkü onlar alışmış kendi başına bir şeyler yapmaya." şeklinde ifade etmiştir. Kaba motor becerilerinin normal düzeyde olduğunu savunan Ö4 ise "Benim öğrencilerim de fiziksel olarak çok büyük bir fark olmadı. Yani diğer çocuklardan ayrilacak bir fark gözlemlemedim. Fiziksel olarak. kaba motor işleri bir şekilde yapıyorlar ama ince beceriler de çok zorlandılar." şeklinde ifade etmiştir. Benzer olarak Ö5 "Fiziksel herhangi bir farkı yoktu.... ama Tuana'ya diyordum ki yarısını yazsın, çünkü yoruluyordu. Çünkü kasları zayıf, kalem tutmakta zorlanıyordu; öğrenmesinde sorun olmamasına rağmen." 
Okul öncesi eğitimi almayan ve ilkokula erken yaşta başlayan çocukların el kaslarının gelişmediğini savunan Ö3 şu şekilde ifade etmiştir : "Sadece el kastları çok zayıftı. Anasınıfina gitmeyenler de problem vardı ama Anasınıfina giden öğrencilerin motor becerileri gayet iyiydi."

Veliler tarafından da en sık tekrar edilen veri $(f=3)$ el kaslarının gelişmemiş olmasıdır. Bununla ilgili olarak V1 "Yazıda el kasları da gelişmediği için yazılar ona çok uzun ve sıkıcı geliyordu. El yazısı ile başladığımız için karmaşıklık onun için arttı." Benzer olarak V5 "Arda'yla çok uğraşıyoruz. 3 saat falan hadi yap, hadi yapalım oğlum, diyorum. O sürekli azıcık araba oynayayım , azıcık oyun oynayayım, biraz televizyon izleyeyim, elim yoruldu, kolum ağrıyor, diyor ödev yapmaktan vazgeçiyoruz."

Bilişsel alanla ilgili olarak çoğu katılımcı $(f=4)$ erken yaşta okula başlayan çocukların algılamasının diğer çocuklardan bir farkı olmadığını ancak psikomotor alanda ince motor gelişimi zayıf olduğu için yapamadıklarını şu şekilde ifade etmişlerdir:Ö1 "Algılama üçüncü sınıf seviyesine kadar diğerleri ile ayn seviyede", Ö2 "Çocuğun gelişiminde bir problem yoksa bilişsel olarak bir sorun yaşamadık gibi algılaması diğer yaş grupları ile aynıdı anlayabiliyordu ama yapamıyordu mesela yaptırmaya çalıştı̆̆ım şeyi anlıyordu ama yapamadığı için zorlanıyordu.", Ö5 "Akademik anlamda kendinden büyük olanlardan çok daha önce öğrendi. Bir yıl sonra başlamış olsa sınıfın lider öğrencilerinden olurdu, en zeki öğrenciler arasında olurdu. Algılaması çok iyiydi. Ama kasları zayıf, kalem tutmakta zorlanıyordu.", V3 "ilk zamanlar ödevde sikıntımiz oldu, yapmakta zorlandı, yazmada olsun zorlandı. Hani yapamıyorumcasına bir zorluk vardı. Yapmayı öğrendikten sonra zaten kendiliğinden ödevlerini yapıyor."

Bilişsel alanla ilgili olarak erken yaşta okula başlayan öğrencilerin okuduğunu anlamakta sıkıntı yaşadığını belirten Ö3 şu şekilde ifade etmiştir : "Hepsi okuma yazmayı öğreniyor, hepsi demeyeyim de çoğu. Ama anlamaya yönelik çalışmalarda matematik olsun, hayat bilgisi olsun, düşündüğ̈̈nü söyleme olsun, düşündüğünü yazma, cümle kurma, bunlarda zorlanıyorlar." Benzer şekilde V2 algılamada zorlandığını şu şekilde ifade etmiştir: "Ödevlerinde çok zorlandı aslında. Toplama çıkartma da çok zorlandı. Bazı konuları tam anlayamadı bu zorluklarda ben de yardımo olmaya çalışıyorum. Mesela konuları anlatıyorum, ağabeyleri anlatıyor, o da çözüyor. Evde tekrar yapıyoruz." 
Erken yaşta okula başlayan çocukların bilişsel olarak hazır olmadıklarını Ö4 şu şekilde ifade etmiştir : “...Ama Yusuf öğrencinin ailesi; yaşı küçüktür, biraz bir erken verdik olur böyle şeyler deyip bunlarn çok önemsemedi, üzerine düşmediler. O yüzden orada çok zorlandık. Hani ben dedim yani bunu madem erken verdiniz, vermeyin dedim ama verdiniz, bari gereğini yapın. Yani ilgilenin. Diğer veliler bir ilgileniyorsa, sizin bununla iki ilgilenmeniz lazım, diyerek uyarmıştım ama yetişemedi." Benzer şekilde V5 "Okumazsam yapamıyor kendi başına. Ben okuyorum, babası okuyor. Hala da devam ediyor sıkıntı. Ben soruyu okuyordum o cevap veriyordu, şıklara falan doğru yapıyor. Ama kendisi okumada zorlanıyor, hep yanlış yapıyor, anlamıyor." görüş belirtmiştir.

Öğretmenlerin tamamı ilkokula erken yaşta başlayan çocukların uyum sorunu yaşadığını düşünmesine rağmen velilerin çoğu $(f=3)$ uyum problemi yaşanmadığını düşünüyor.

Katılımcılar tarafından en çok paylaşılan $(f=4)$ arkadaşlık kurmadasıkıntı yaşaması ile ilgili olarak Ö5 "Arkadaş edinmekte zorlandı. Çünkü diğerleri çabuk adapte oldular, çabuk alıştılar. Onlar konsantre olup oyunlarını etkinliklerini yaparken, Tuana'nın aklına anne düşünce kopuyordu sinıftan. O tamamen eli alnında anneyi bekliyordu.", V2 "Okuldaki arkadaşlarıyla ona çok zor oluyor. Arkadaşlarıla yaşıt değiller. Onlar 1 yaş ondan büyük.", V5 "Kendinden büyük yaşlı çocuklar olduğu için Arda pimi çekilmiş bomba gibiydi."şeklinde ifade etmişlerdir.

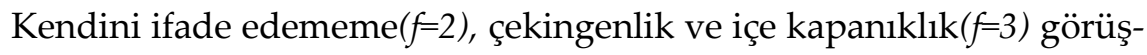
leri erken yaşta okula başlayan öğrencilerde sosyal duygusal gelişim alanında yaşanan sorunlar olduğunu Ö2 "Evet dediğim öğrenciler çok duygusallardı. Sosyal olarak da çok içine kapanıkt. Mesela oyun oynayacağımız zaman oyun ve fiziki etkinlikler dersinde çekiniyorlardı, kalkmıyorlardı, gelmiyorlardı... büyük yaşlar küçük yaşları ezebiliyordu işte; sen yapamıyorsun, sen küçüksün, o yapmasın, grup çalışması olduğunda o girmesin, o yapamıyor, gibi sorunlar oluyor. Bu da içe kapanmasına sebep oluyordu. Onu daha çok motive etmemiz gerekirken arkadaşları böyle yapınca üzülüyorlardı." şeklinde ifade etmiştir. Benzer şekilde V2 "Bence bir sene sonra başlasaydı daha çok kendimi korurdu, daha becerikli olurdu. Şu an kendini tam koruyamıyor, istediğim gibi değil. Kendini ifade edemiyor." görüş belirtmiştir. 


\section{İlkokula Erken Yaşta Başlayan Öğrencilerin Uyum Sürecine İlişkin Bul- gular}

Araştırmada ilkokula erken yaşta başlayan öğrencilerin uyum sürecine ilişkin görüşlerin nasıl olduğunu saptamak amacıyla öğretmenlere "İlkokula erken yaşta başlayan öğrencilerin okula uyum sürecini nasıl değerlendiriyorsunuz? Öğrencilerinizin bu süreçte uyum sorunu yaşadiğın düşünüyor musunuz? Ne gibi uyum sorunları yaşadıklarma örnek verebilir misiniz?"; velilere "Çocuğunuzun erken yaşta ilkokula başlamasindan dolayı evde gözlemlediğiniz ve okul ortamına da yansiyan uyum sorunlar var mi? Varsa nelerdir?" soruları yöneltilmiştir. Bu soruya verilen cevapların analiz edilmesiyle ortaya çlkan sonuçlar Tablo 4'te verilmiştir.

Tablo 4. İlkokula Erken Yaşta Başlayan Öğrencilerin Uyum Sürecine İlişskin Bulgular

\begin{tabular}{lll}
\hline Görüssler & f & Katılımcılar \\
\hline Tirnak yeme & 1 & V1 \\
Saldırganlık & 2 & Ö2,V5 \\
Alt 1slatma & 4 & Ö1,Ö4,Ö5,V5 \\
Okul fobisi & 3 & V1,Ö2,Ö3 \\
Çekingenlik, utangaçlık & 3 & Ö2,Ö4,Ö5 \\
Anneye bağllık & 2 & Ö4,Ö5 \\
Başarısızlık korkusu & 1 & Ö4 \\
Takıntı & 1 & Ö4 \\
İletişim sorunları & 1 & Ö5 \\
Okuldan kaçma & 1 & Ö2 \\
Okul öncesi eğitimi alanlarda uyum sorunu olmadı & 3 & Ö2,Ö4,V4 \\
Uyum sorunu olmadı & 3 & V2,V3,V4 \\
\hline
\end{tabular}

Tablo 4'te yer alan bulgular değerlendirildiğinde uyum sürecine ilişkin rastlanan sorunlardan alt ıslatma öğretmenlerin çoğu ve bir veli tarafından ifade edilmiştir $(f=4)$. Bununla ilgili olarak Ö1 "Tuvalet ihtiyacını tam karşılayamıyor, bazen ıslak oluyor. Tuvalete yetişemiyor altına kaçırıyor", Ö5 ise "Kesinlikle uyum sorunu yaşadik; alt ıslatma problemi yaşadık. Sonra annem ne zaman gelecek?, ben annemi ne zaman göreceğim? diye sormaya başlıyordu. Ilk 3 dersten sonra anneyi özlemeye başlayınca o içine kapanıklı hali, alt ıslatma falan onlar başlıyordu. Bu 2 ay boyunca devam etti."şeklinde ifade etmişlerdir. Katılımcılardan V5 ise alt islatma sorununun okula uyum sağladıktan sonra geçtiğini şu şekilde ifade etmiştir: "Vardı. 
Haftada 2 defa altını ıslatma olayı vardı. Altını ıslatma problemi kendi kendine geçti, okula adapte olduktan sonra."

Katılımciların çoğu erken yaşta ilkokula başlayan öğrencilerde alt 1slatma sorunu dişında en fazla çekingenlik,utangaçlık $(f=3)$ ve okul fobisi $(f=3)$ sorunları yaşadıklarını belirtmişlerdir. Bununla ilgili olarak Ö2 "Kesinlikle uyum problemi yaşıyorlar, sosyalleşme de problem yaşıyorlar...okuldan kaçmaya çalışıyordu. Utangaçlık, mesela bana gelip tuvalete gidebilir miyim? diyemiyordu... biraz eziklik yaşıyordu kendi içinde bir şey yapamadığı zaman, hemen alınıyorlardı küçük oldukları için. Bir öğrencim de okul fobisi erkek öğrencim o bıraktı okulu, yani sınıfta kaldı" şeklinde ifade etmiştir. Ö4 ise çekingenliklerini şu şekilde ifade etmiştir. "Çok çocuksulardl, sürekli ağllyorlardl, hemen küsüyorlardı. Dersin ortasında kendiliklerinden başka şeyler yapıyorlar, konuşuyorlar, sını düzenine uyum să̆layamadılar. Çok ağır geldi, zor geldi. Önlerine kağıt verdiğim zaman, yapmak istemiyorlardr. Ben işte boyamak istemiyorum, yazmak istemiyorum, ondan sonra gitmek istiyorum..." Öğrencisinin okul fobisi yaşadığınıÖ3 “Annesini bırakıp gitme noktasında bazen sorunlar yaşayabiliyorum... okula gelmek istemiyor, sürekli karnı ă̆rıyor. O öğrencim ă̆layan karnı ă̆rıyordu sürekli. Aslında karnının ağrıdığını düşünmüyorum. Psikolojik ağrı olduğunu düşünüyorum. Çünkü bizim ilerlediğimizi gördükçe, ben onun geride kaldığını kalabalık bir sinıfta 35 kişilik bir sınıfta bazen ağladığın da fark edebiliyordum" şeklinde belirtmiştir. Ö5 ise erken yaşta ilkokula başlaması dışında tek çocuk olmasının yaşadığı çekingenlikle bağlantılı olabileceğini “...tek çocuk olduğundan kaynaklı belki, annesine çok düşkün olduğu için olabilir.Anneye bağımlıydı...onun uzun sürdü kesinlikle, uyum sorunu yaşadık ... daha çok içe kapanma... anneyi özlemeye başlayınca o içine kapanıklı hali alt ıslatma falan onlar başlıyordu. Arkadaş edinmekte zorlandı... kapris yapabiliyordu diğerlerine göre adapte olmakta daha zorluk yaşadı. Diğer çocuklar dışlayıcı değildi o kendini soyuluyordu."şeklinde ifade etmiştir.

Öğretmenlerden Ö4 başaramama korkusu ve takıntı sorununun aileden kaynaklanabileceğini şu şekilde ifade etmiştir: “... ailede çok rahat değildi bence. Aileden gelen bir takıntısı vardı ya da babadan bir korkusu vardı. Ellerini, ayağın ya da bacă̆ın sürekli sallıyordu, vazgeçemiyordu. Çekingendi çok. Bence biraz başaramadım, beceremedim gibisinden kaynaklanıyor. Öyle bir korkusu vardı." 
Katılımcı velilerin öğrenim düzeylerine bakıldığında ilkokul mezunu olan V2,V3,V4 çocuklarının ilkokula erken yaşta başlaması ile ilgili sorun yaşadıkları ancak bunların uyum sorunu olmadığını belirtirken; lise mezunu V5 alt ıslatma dışında saldırganlık sorunu yaşadığını şu şekilde ifade etmiştir: "... akşamlar çıkışta öğretmenimiz hep uyarıyordu; arkadaşlarıyla sürekli tartışıyor, sürekli kavga ediyor diye. Sadece kendi sınıfımızda değil, diğer sinıflardaki arkadaşlarıla da kavga ediyordu. Zor bir dönem atlattım." Üniversite mezunu V1 çocuğunda tırnak yeme sorununun ve okul fobisinin ilkokula erken yaşta başlamasından kaynaklandığını şu şekilde ifade etmiştir: "Evet tırnak yeme, okul fobisi. Ancak bunlar okula gelene kadar yaşanıyor. Sinıf içinde bu tarz problemler yaşanmıyor bence. Şu an 3. sinıf evde hala tırnak yiyor, her gün bugün okul var mı diye uyanıyor." Illkokula erken yaşta başlayıp uyum sorunu yaşamadığını belirten V4 bunun bir sene süreyle okulöncesi eğitime gitmiş olmasıyla ilişkilendirmiştir. Bununla ilgili olarak V4 “...yok çok uyumluyuz. O konuda fazla gözü açıldı diyebilirim. Biz zaten kreşe gidiyorduk. Bir sene kreşe gitti. O yüzden alışkındı."

Okul öncesi eğitim alan çocuklarda ilkokula erken yaşta başlasalar da uyum sorunu gözlemlemediklerini $(f=2)$ Ö2 “.... ama biraz okul öncesi eğitim almış olanlar çok girişkendi. Onlar mesela sayıları biliyorlar, oyun oynamayı biliyorlardı. O öğrencim çok seviyordu çalışmayı, okumayı..." şeklinde ifade etmiştir.

\section{İlkokula Erken Yaşta Başlayan Öğrencilerin Akademik Başarılarına İlişkin Bulgular}

Araştırmada ilkokula erken yaşta başlayan öğrencilerin akademik başarılarına ilişkin görüşlerin nasıl olduğunu saptamak amacıyla öğretmenlere "Öğrencilerinizin akademik başarıların değerlendirme ölçütleriniz nelerdir? İlkokula erken yaşta başlayan öğrencilerin akademik başarılarım nasıl değerlendiriyorsunuz? Öğrencinin gelişim düzeyi ile akademik başarı arasında nasıl bir ilişki vardır?"; velilere "Çocuğunuzun akademik başarısını okula erken başlamış olması açısından nasıl değerlendiriyorsunuz? Sizce okula bir sene sonra başlasaydı daha başarılı olur muydu?" soruları yöneltilmiştir. Bu soruya verilen cevapların analiz edilmesiyle ortaya çıkan sonuçlar Tablo 5 'te verilmiştir. 
Tablo 5. İlkokula Erken Yaşta Başlayan Öğrencilerin Akademik Başarılarına İlişkin Bulgular

\begin{tabular}{lll}
\hline Görüsşler & f & Katılımcılar \\
\hline Algılamada problem olmadığı için başarılı & 3 & Ö2,Ö5,V3 \\
Kas gelişiminden dolayı başarısız & 3 & V1,V3,V5 \\
Kendini ifade edemediği için başarısız & 1 & V2 \\
Çekingen olduğu için başarısız & 1 & Ö2 \\
Anlayamadığı için başarısız & 3 & Ö3,Ö4,V5 \\
Sınıftan geri kallyor, başarısız & 3 & Ö1,Ö3,Ö4 \\
Yaş büyüdükçe başarı artar & 8 & V1,V2,V5,Ö1,Ö2,Ö3,Ö4,Ö5 \\
Yaşla başarı arasında ilişki yoktur & 2 & V3,V4 \\
\hline
\end{tabular}

Tablo 5'te elde edilen bulgular değerlendirildiğinde katılımcıların çoğu $(f=8)$, öğretmenlerin tamamı, akademik başarı ve yaşın doğru orantılı olduğunu ifade etmişlerdir. Bununla ilgili olarak; Ö1 "Yaş büyüdükçe başarı artıyor. Erken yaşta başlayan çocuklar ileri yaşta başlayanlardan mutlaka geri kahyorlar.",Ö2 “Büyük olan daha başarılıdır. Daha ileride gidiyor her zaman. Mesela 23 Nisan'da şiir ezberlenecek, hep o büyük olanlar yapmak istiyor, küçük olanlar biraz daha çekinik kalıyor, yapamam düşüncesi oluyor.",Ö4 "Mesela bugün. Diyor ki silindirin yüzeyleri; silindirin üst yüzeyinin ve alt yüzeyinin yuvarlak olduğunu. Algllayamayacă̆ın düşünüyorum. Tam yaşında olan öğrenci bile algllayamazken, erken yaşta başlayanların algılayamayacă̆ın düşünüyorum ve performansı da etkileyeceğini düşünüyorum" Katılımc1 velilerden üniversite mezunu olan V1 "Evet. Sınıfinda yürüme aşamasındaysa bir sene sonra başlasa koşan lider olan bir çocuk olurdu."Lise mezunu olan V5 ise "Keşke yaşıtlarıyla gitseydi daha iyi olurdu. Çünkü şu an hala başarılı değil, geriden geliyor." şeklinde ifade etmişlerdir.

Velilerin çoğunluğu çocuklarının kas gelişiminden dolayı başarısız olduğunu ifade etmiştir. Ancak öğretmenlerin hiç biri başarı ölçütü olarak buna değinmemiş; bu ve benzer faktörlerin etkisiyle sınıftan geri kalmasını başarısızlık olarak değerlendirmişlerdir. Bununla ilgili olarak katılımcı velilerden V1 “... ancak kas gelişimi ona başarısızlı̆̆ tattırdı. Sürekli hiçbir şeye yetişememek onu okuldan uzaklaştırdr.", V3 "Güzel. İlk zamanlarda kalem tutma da problem yaşadı. Kalem tutarken elleri acıyordu. İlk zamanlar bir de öğrenirken çok yazıyorlar ya o yüzden parmakları çok acıyor, o zaman biraz başarısızdi. 1-2 ay sonra geçti gitti."görüş bildirmişlerdir. 
Öğretmenler başarıyı farklı boyutlar açısından değerlendirmiştir. Öğretmenlerden 2 si erken yaşta ilkokula başlayan çocuğun algılaması iyi düzeyde olduğu için başarılı olarak değerlendirmiştir. Ö2 "Ĕ̆ger çocuğun bilişsel gelişimi iyi ise bu etkinliklerde bir fark olmuyor.", Ö5 "Benim öğrencimde olmadı aslında. Daha düşük olması beklenirdi ama olmadı. Ama vaktinde başlamış olsaydı çok daha iyi olabilecek bir çocuktu...farklı değgrlendiriyorum. Sadece okuma yazma ve dört işlemle değerlendiriyor öğretmen, o çocuk başarısız gözükebilir öğretmeninin gözünde. Çünkü kasları zayıf olduğu için çok az yazabiliyor diğerlerine göre." ş̧eklinde ifade etmişlerdir.

Akademik başarıyı bilişsel olarak değerlendiren katılımcılar, erken yaşta okula başlayan öğrencilerin anlayamadığı için başarısız olduklarını şu şekilde belirtmişlerdir: Ö3 “Bence başarıları düşük...güzel okuyor ama anlamaya yönelik etkinliklerde veya yazmaya yönelik etkinliklerde çok geri kalıyor.", V5 "Ben okuduğumda hiçbir sıkıntı yok, hepsini doğru cevaphyor ama kendisi okuduğunda çok geri kalıyor, anlayamıyor."

Gelişim alanlarındaki yetersizliklerden dolayı sınıftan geri kaldığı için bu çocukların başarısız olarak değerlendirildiğini; Ö1 "Konular ağırlaştıkça yaşının küçüklü̈̆̈̈̈nden dolayı yetişemediği fark ediliyor. Dünden daha iyi ise, bir doğru fazla yapıyorsa, davranışlarında olumlu değgişimler oluyorsa, bence o öğrenci başarılıdır. Ancak yaşı küçük olanlar hep geride kalıyor. Çocuk okula gelmek istemiyor. Okuma yazma herhangi bir gelişme olmad..",Ö3“"Verdiğim kazanımları yerine getirebiliyorsa, öğrenebiliyorsa başarılıdır. Zaman zaman sözlü olarak sinav ya da dersler ilerledikçe yazll olarak test etmeye başladım. Verdiklerimi alabilmişlerse, yapabiliyorlarsa benim için başarılı demektir. Ancak yaşı küçük olanlar kazanımları yerine getirmekte diğerlerinden eksik kahıor çoğu zaman.",Ö4"Yani her öğrenciyi kendi açısından değerlendirdiğim için, bir aşamada az yapıyorsa, kendisini aştıysa başarılıdır. Tamam erken başlayanlar sınıf gibi değil, arkadaşları gibi değil, daha gerideler fakat kendini kendisiyle değerlendiriyorum." şeklinde ifade etmişlerdir.

Katılımcı öğretmenlerden Ö2 algılamada problem olmadığı için başarılı ancak çekingen oldukları için başarısız olmasını sosyal duygusal gelişimle ilişkilendirmiştir. 


\section{İlkokula Erken Yaşta Başlayan Öğrencilerin Hazırbulunuşluk Düzeyine İlşkin Bulgular}

Araştırmada ilkokula erken yaşta başlayan öğrencilerin hazırbulunuşluk düzeylerine ilişkin görüşlerin nasıl olduğunu saptamak amacıyla öğretmenlere "Illkokula hazırbulunuşluk için kazanılması beklenen beceriler sizce neler olabilir? İlkokula erken başlayan öğrencileriniz bu becerileri kazanmış mıydı?" ; velilere "Çocuğunuzun erken yaşta ilkokula başlamasını neden tercih ettiniz? İlkokula erken yaşta başlamasına hazır olduğuna nasıl karar verdiniz " soruları yöneltilmiştir. Bu soruya verilen cevapların analiz edilmesiyle ortaya çıkan sonuçlar Tablo 6 'te verilmiştir.

Tablo 6. İlkokula Erken Yaşta Başlayan Öğrencilerin Hazırbulunuşluk Düzeyine ilişkin Bulgular

\begin{tabular}{lll}
\hline Görüsşler & f & Kat1lımc1lar \\
\hline El kasları & 5 & Ö1,Ö2,Ö3,Ö4,Ö5 \\
Sinıf disiplini & 1 & Ö1 \\
Hevesli, istekli olmas1 & 5 & Ö3,Ö4,V2,V3,V4 \\
Alg1lama düzeyi & 1 & V1 \\
Azimli, hırslı & 1 & V4 \\
Illkokula başlamaya hazır değil & 7 & Ö1,Ö2,Ö3,Ö4,Ö5,V2,V5 \\
Hazırbulunuşluk başarı ile doğru orantıl1 & 4 & Ö1,Ö2,Ö3,Ö4 \\
\hline
\end{tabular}

Katılımcıların çoğunluğu $(f=7)$ çocuğun ilkokula hazır olmadı̆̆ını, hazır bulunuşluk düzeyinin düşük olduğunu belirtmiştir. Katılımcılardan V2 eşinin zoruyla ilkokula yazdırdığını "Anasınıfına gidecekti. Babası $k ı z$ çocuğudur, 1 sene önce gitsin dedi ...Ben anasinıfina göndermek istedim. İlkokula hazır olduğunu düşünmedim ama eşim öyle istedi" diyerek belirtmiştir. Öğretmenlerin tamamı ilkokula hazır bulunuşluk için el kaslarının gelişmiş olmasını belirtmiştir. Bununla ilgili olarak; Ö2“Bir kere psikomotor becerileri kazanmış olması lazım. Kalemi tutabilmesi lazım. Yanlış tutsa bile daha öncesinde o karalama çalışmasını yapmış olması lazım. Bir de davranış olarak da hazır olması gerekiyor. Çünkü çok küçük çocuklar dediğim gibi uyum să̆layamıyor, saldırgan olabiliyor.",Ӧ3 "Bu hazırbulunuşluk da değillerdi. Kalem tutamıyorlar, makas kullanamıyorlar, boyama yapmıyorlardı. Sıkılıyorlardı. Veya çocuktan beklenen taşırmadan boyama yapmak. Zor, onları yapamıyorlar.",Ö5 “... makas tutma çok önemli. Makas tutmada el göz koordinasyonu çok önemli. Onu yapabiliyorsa en azından yazma da sorun 
yaşamıyor çocuk. En önemlisi bence makas tutma ve şeklin içini doldurma. Tuana tam olarak kazanmamıştı... kesmeye başlarken, o resmin ortasından kesiyordu. O sabrı gösteremiyordu. Kesemediği yerde eliyle yırtıyordu.",Ö4 “...ikincisi fiziksel olarak kesinlikle gelişmiş olmalı. El kasları gelişimi, zaten olmalı." şeklinde ifade ederlerken; Ö1 hazırbulunuşluk için kazanılması gereken diğer bir ölçütün sınıf disiplinine uyum sağlaması olduğunu şu şekilde belirtmiştir: Ö1“...anaokulları kes yapıştır da öteye geçmeli artık. Çocuklar anaokullarında okul kurallarına, düzenine ve sınıf disiplinine alıștırılmalı"

Velilerin çoğunluğu hazır bulunuşluğu çocuğun istekli ve hevesli olmasıyla ilişkilendirmiştir. Bu durumu V2 “... çok istekliydi çocuk, okulu seviyordu. Onun için erken verdim.", V3 "Evde o kadar çok sıkılıyordu ki ben okula gitmek istiyorum diyordu. Çok sık dile getiriyordu bunu. Evde de sıkıldığı için o yüzden yazdırdım... ilkokula hazır olduğunu düşündüm. Çok hevesliydi, çok istiyordu. Okumayı istiyor, ablasına sorular soruyordu. Abla bu harfin adı ney? , abla şu harfinin adı ney? , şu nasıl okunuyor? falan diye, ablasina sorular soruyordu.", V4 "Kendisi çok istedi. Beni bu sene göndermezseniz daha da gitmem gibisinden konuştuğu için. Hani bir de yapabileceğine inandım. Çünkü çok hırslı, çok kıskanıyor, o kıskançlık biraz hırsa dönüştü. O yüzden çok azimli. Bunu bildiğim için ona karşı o yüzden tamam dedim." şeklinde ifade etmişlerdir.Bununla ilgili olarak öğretmenlerden Ö4 ise "Bir kere duygusal olarak kendine okula gideceğim demeli. Yani çocuk kendi demeli... istekli olmalı çocuk. Çünkü iş başa düştüğ̈̈̈nde yapacak kişi çocuktur. Anne isteğiyle baba isteğiyle olacak şey değil!" şeklinde belirtmiştir.

Katılımclardan V1, algılama düzeyi iyi olduğu için ilkokula hazır olduğunu "Anasinıfina gitmeyi kabul etmedi. Bu sebeple hazır olduğunu düşündüm. Algılamada sıkıntısı yoktu. Bu yüzden başlattık." diyerek belirtmiştir.

Öğretmenlerin çoğu öğrencinin hazır bulunuşluk düzeyi ve başarı arasında doğru orantı olduğunu ifade etmiştir. Ö1 "El kasları yeterince gelişmediği için tahtayı geçirmekte, çalışmaları tamamlamakta sürekli geç kaldı. Başarısızlık onu artık rahatsız etmemeye başladı. Nasıl olsa küçüğüm, nasıl olsa yapamam diyerek, başarısızlı̆̆ı kabullenmeye başladı.",Ö2 “Hep ablasına yaptırıyormuş ödevlerini. Aynı sınıfta oldukları için o bana gelip hep söylüyordu. Bana yaptırlyor diye. Yani çok başarılı olamadı onun için.",Ö3 "Şu an dersler ilerledikçe; Matematik, Türkçe, konular ağırlaştıkça, biraz geri kalmaya başladı. Yani sadece okuma yazma ile iş bitmiyor. Veya hevesli olmayla, istekli 
olma ile bu iş bitmiyor. Ben bunu yaşının kü̧̈üklü̈̆̈̈ne de veriyorum. Çünkü çok küçük. Sinıfin en küçü̈̆̈̈." şeklinde ifade etmişlerdir.

\section{İlkokula Erken Yaşta Başlayan Öğrencilerde Görülen Sorunlarla Baş Etmede Kullanılan Yöntemlere İlişkin Bulgular}

Araştırmada ilkokula erken yaşta başlayan öğrencilere yönelik sınıf içinde yapılan düzenlemelere ilişkin öğretmenlere "Farkl yaş grubundaki öğrencilerle bir arada çalışma ile ilgili sımıfınıda ne gibi düzenlemeler yaptınız? Psikomotor, bilişsel ve sosyal duygusal gelişim alanlarıyla ilgili çözüm olarak yapılabilecek düzenlemeler neler olabilir? İlkokula erken yaşta başlayan öğrencilerin okula uyum sağlaması sürecinde nasıl bir yol izlediniz? İlkokula hazır bulunuşluk becerilerinin sağlanması için neler yaptını??"; velilere "Öğretim süreciyle ilgili evde yaşadığınız zorlukları nasıl aştınız? Öğretmeniniz öğretim sürecinde yaşanan zorluklar ile ilgili evde uygulamanıza yönelik size ne gibi öneriler sundu?" soruları yöneltilmiştir. Bu soruya verilen cevapların analiz edilmesiyle ortaya çıkan sonuçlar Tablo 7'de verilmiştir.

Tablo 7. Ilkokula Erken Yaşta Başlayan Öğrencilerde Görülen Sorunlarla Baş Etmede Kullanılan Yöntemlere İlişkin Bulgular

\begin{tabular}{lll}
\hline Görüşler & f & Katılımcilar \\
\hline Görmezden gelme & 1 & V1 \\
Konuşup rahatlatma, teşvik etmek & 5 & Ö2,Ö4,Ö5,V3,V5 \\
Anasinıfina yönlendirme & 3 & Ö1,Ö2,Ö3 \\
Rehberlik servisinden destek almak & 2 & Ö1,Ö3 \\
Veli ile görüşme, işbirliği & 5 & Ö1,Ö2,Ö3,Ö4,Ö5 \\
Uyum haftası & 3 & Ö1,Ö3,Ö4 \\
Oyun, eğlenceli etkinlikler & 4 & Ö2,Ö4,Ö5,V4 \\
Grup çalışması, akran eğitimi & 3 & Ö2,Ö3,Ö5 \\
Uyarma & 2 & Ö1,V1 \\
Birebir eğitim & 3 & Ö2,Ö3,Ö4 \\
Tekrar etme & 3 & Ö1,V2,V5 \\
Ödül & 2 & Ö1,V5 \\
Kitap okumak & 2 & V2,V5 \\
Zorlamamak & 3 & V1,V3,V4 \\
El kaslarını geliştirici etkinlikler & 4 & Ö1,Ö2,Ö5,V3 \\
Drama & 2 & Ö1,Ö5 \\
\hline
\end{tabular}

Katılımcilar tarafından en sık tekrar eden veri $(f=5)$ konuşup, rahatlatma, teşvik etmedir. Bununla ilgili olarak Ö4 “...konuşmalar yaptım. 
Ağladıklarında böyle algıladılar: Okula gelmemiz gerekli. Sıkıntı yaşamadılar. Fakat derse geçtiğimizde, oradaki zorluğu görünce, yapacaksınız dedim. Ama çocuğa anlatamıyorsunuz $k i$, daha yaşın küçük, biraz ilerleyince bunu yapacaksın, diyemiyorum.", Ö2 "Dersimde çekiniyorlardl, kalkmiyorlardl, gelmiyorlardı. Hep ben çağırıyordum onu ya da konuşturmaya çalışıyordum.", V3 "Zaman zaman sen yapacaksın, çok güzel yapıyorsun diye hani gaz vererek daha bir iştahla yaptı ödevlerini, heveslendi...evde böyle olunca kendini çekiyor. Onu konuşturmak için soruyorum sürekli. İlk başta anlatmıyor, anlatabilirsin, rahat ol dediğim zaman çözeriz bakalım bir rahatladıktan sonra varsa bir problem anlatıyor, güven veriyorum." şeklinde ifade etmiştir.

Katılımcı öğretmenlerin tamamı $(f=5)$ ilkokula erken yaşta başlayan öğrencilerde görülen sorunların veli ile görüşme, işbirliği yaparak çözülebileceği görüşündedir. Ö2 “...velileri arıyordum bu konularla ilgili. Ama benim gittiğim yer köydü. Veli ziyareti yaptığımız zaman velilerle iletişim kurabiliyordunuz sadece.",Ö5 "Annesiyle konuştuk sürekli olarak. Annesi de üniversite mezunu olan bir hanımdl, o da destek verdi ama onu alıştırmamız çok zor oldu. 2. sinıfa başladığında da aynı davramışları gösterdi ama daha kısa sürdü.", Ö1“...yaşının küçük uyum konusunda problem yaşamasının normal olduğunu ifade ediyorum. Veli ile işbirliği yoluyla sorunları aşıyoruz." Ö4 "Biraz da aile ile ilgili olduğunu düşünüyorum. Sakin oluyordum. Yaşının küçük olduğunu bildiğim için hep alttan aldım sakinleştirdim, yapacaksin dedim ama aileye döndüğ̈̈mde bakın bu sebepten daha küçük, daha buna ă̆ır geliyor, aileye açıklama yapıyordum, çocuğu sakinleştiriyordum." ifade etmişlerdir.

Katılımcı öğretmenler tarafından tekrar eden diğer veriler ise yönlendirme yapılması ile ilgilidir. Bu bağlamda rehberlik servisinden destek almak $(f=2)$ ve anasınıfına yönlendirme $(f=3)$ verileri ile ilgili olarakÖ1 “...anlaşma konusunda rehberlik biriminden destek alıyorum.”, Ö3 "Şimdi bu küçük gelen öğrencilerle baktım yapamıyorlar, devam edemeyecekler, yaşları da küçük, ana sınıfına da gitmemişlerdi, o yüzden velilerle konuşarak, rehber öğretmenlerle konuşarak bir iki tanesini anasmufina yönlendirdim." şeklinde görüş bildirmişlerdir.

Katılımcı öğretmenler ilkokula erken yaşta başlayan öğrencilerde görülen sorunların çözümünde grup çalışması ve akran eğitiminden $(f=3)$ yararlandıklarını şu şekilde ifade etmişlerdir: Ö3 “...diğer çocukların onlara yaklaşımlar çok iyiydi, yardım ediyorlardı. Şimdi zaten uyum sürecini bir hafta iki hafta kısıtlı bir dönem. Sonrasında arkadaşları da yardım etmeye 
çalıştı.", Ö5 "Birebir sadece onun için özel bir çalışma yapmadım. Oyun gruplarında grup çalışmaları çok yaptırıyordum. Böylelikle iletişim sorunların aştık. Bir süre sonra erken yaşta başlayan çocukta arkadaş edinme sorunu ortadan kalktı."şeklinde ifade etmişlerdir.

Katılımcı öğretmenler birebir eğitim $(f=3)$ ile el kaslarını geliştirici etkinlikler $(f=4)$ uyguladıklarını şu şekilde ifade etmişlerdir: Ö3 "Hani ellerinden tuttum, yanlarına oturdum. Sürekli yaptırmaya uğraştım, çalıştım ama bir yerden sonra onlar da yoruldular ve devam edemediler.", Ö2 “...ben ona mandalla kalem tutmayı öğrettim. Mandalın hepsini tutuyordu, tutamıyordu. Sonra alışamadı, mandalı kırdı.", Ö4 "...sorun biraz derse başlayınca oldu. Birebir ilgileniyordum. Bu becerileri kazanması için yanıma çağırıyordum. Okumaya geçse bile ekstra çalışmalar yapıyordum.",Ö1 "Bu çocuklara hamurla oynamak kesme-yapıştırma gibi etkinlikler veriyorum."

Katılımcılardan Ö1kullandığı alternatif yöntemleri şu şekilde ifade etmiştir: "Okuma anlama çalışmaları, soru cevap etkinlikleri, drama yolu ile bilişsel gelişim etkinlikleri. Tekrar etme ve uyarma yaparım. Ödül kullanırım ceza kullanmadım."

Oyun ve eğlenceli aktiviteler $(f=4)$ ile ilgili olarak Ö2 "Ben genelde böyle eğlenceli etkinlikler yapmaya çalışıyordum; okula gelmek istesinler, okulu sevsinler diye. Onun dişında çevreyi özellikle gezdiriyorum.",Ö5 “Sınıfa girdiğimde mutlaka egzersiz ve oyun rahatlama egzersizi kesme yapıştırma etkinliği veriyordum onlara. Aralarda sıkıldıkların anladı̆̆ın anda mutlaka bir oyun küçük bir drama ya da ben hikaye okuyup onlardan canlandırmalarn istiyordum. Yani altı dersin üçünde çok yoğun akademik ders yapıyorsam, diğer üçünde onları rahatlatacak bir oyunla eğlendirecek etkinlikler yaptım. Müzikle rahatlatıcı etkinlikler yaptım.", V4 "ilk zaman yaşadığımız zorlukları aşmak için evde bir duvar yaptım. O duvara bütün harfleri, kelimeleri, heceleri yazdım. Öğretmencilik oyunu gibi başında günlerce, aylarca uğraştım Yani biraz da benim azimle okudu da diyebilirim." şeklinde örnekler vermişlerdir.

Katılımcı velilerin çoğunluğu $(f=3)$ öğretmenleri ile yaptıkları görüşmeler sonucu zorlamadıklarını şu şekilde ifade etmişlerdir: V1 "Yaşananlar hep normal dedi öğretmenimiz, bir şey yapmadık farklı problemlerinde etkisi ile görmezden gelmeyi tercih ettim.", V4 "Ekstra ödev vermedi. Bazen başka öğrencilere verdiği ödevi benim kızıma vermedi. Yapabileceğini düşünmüyorum şu anlık hani dedi. Bilerek vermiyorum, yapabileceğini düşünmüyorum, zorlanmasın dedi.", V3 "ekstra bir çalışma önermedi. Ne za- 
man sorsam; biz iyiyiz dedi, bir sıkıntımız yok dedi, problem yok dedi, iyiyiz algılaması dinlemesi falan iyi dedi." Katılımcı velilerden V5 ise ödül yöntemini kullandığına ilişkin "Başarılı olduğu zaman ya da evde derslerini yaptığı zaman, ona hediye alacağız ya da şunu alacağız şeklinde motive ediyoruz." diyerek görüş bildirmiştir. Tekrar etme yöntemine ilişkin V2 “...bu zorluklarda ben de yardımcı olmaya çalışıyorum. Mesela konuları ben ona anlatıyorum ağabeyleri anlatıyor. $O$ da çözüyor, öyle yapıyor. Evde tekrar yapıyoruz.", V5 “Sürekli okuma, tekrar etmesi gerektiğini söyledi bize biz zaten 1. sinıfta Arda için özel ders aldık. Okula gittikten sonra bir saat hep ders verdi öğretmenimiz, onun sayesinde yakaladı çocuk diğerlerini."ş̧eklinde ifade etmişlerdir. V1ise bazen uyarma yöntemi kullandığını "...evde çok zor-

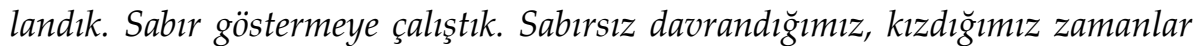
oldu." şeklinde belirtmiştir. Velilerden bazıları $(f=2)$ erken yaşta ilkokula başlayan çocuğun yaşadığı sorunların çözümünde kitap okuduklarını şu şekilde ifade etmişlerdir: V5 “...bazen yardımo oluyorum. Okumazsam yapamıyor kendi başına. Ben okuyorum, babası okuyor.", V2 "Öğretmenimiz evde ödevleri yaptırın, çalıştırın. Bol bol kitap okusunlar dedi. Kitap okuyana yıldız mı ne veriyormuş öğretmen. Çok okuyoruz birlikte evde yıldızı kazanmak için."

\section{İlkokula Erken Yaşta Başlayan Öğrencilerde Görülen Mevcut Sorun- ların Çözümüne İlişkin Bulgular}

Araştırmada ilkokula erken yaşta başlayan öğrencilerin yaşadıkları sorunların çözümüne ilişkin görüşlerin nasıl olduğunu saptamak amacıyla öğretmenlere ve velilere "Sizce ilkokula erken yaşta başlayan öğrencilerde görülen sorunların çözümünde yapılabilecek iyileştirmeler neler olabilir?" sorusu yöneltilmiştir. Bu soruya verilen cevapların analiz edilmesiyle ortaya çıkan sonuçlar Tablo 8'de verilmiştir.

Katılımcıların çoğu $(f=6)$,öğretmenlerin tamamı, ilkokula erken başlatılmaması gerektiğini şu şekilde ifade etmişlerdir: Ö1 “...ve başlatılmamalı 72 aydan önce. 66 aylık başlayan öğrencinin beceri ve yetenekleri 6 ay gecikmeli takip etti. Birebir gözlemledim bunu. 6 ay önce yapamadığını, 6 ay sonra yapabildi ama başarısız oldu. Çünkü küçük başladı.", Ö5 "Bana danışanlara kesinlikle başlatmayın diyorum.",Ö3 “Bence çocuklarının hazırbulunuşluk seviyesine göre gönderirlerse daha iyi olur. Bu da bence 70 ayın üzerinde olma- 
lı.", Ö4 “...ama kesinlikle 7 yaş görmeliler kesinlikle. Gelişimini tamamlamış olması lazım.", V1 "Kesinlikle erken başlamak kabul edilmemeli."

Tablo 8. Illkokula Erken Yaşta Başlayan Öğrencilere Yönelik Çözüm Önerilerine İlişkin Bulgular

\begin{tabular}{lll}
\hline Görüsşler & f & Katılımcılar \\
\hline Kesinlikle erken başlamamalı & 6 & Ö1,Ö2,Ö3,Ö4,Ö5,V1 \\
Okul öncesi eğitim almalı & 5 & Ö1,Ö2,Ö3,Ö5,V2 \\
Oyun dersi & 3 & Ö2,V3,V4,V2 \\
Veli bilinçlendirme çalışmaları & 2 & Ö3,Ö4 \\
Müfredat ağır & 2 & Ö4,Ö5 \\
Sinıf mevcutları azaltılmalı & 1 & V5 \\
\hline
\end{tabular}

Katılımcilar $(f=5)$ okulöncesi eğitim almanın ilkokula erken yaşta başlayan öğrencilerin yaşadıkları sorunlara çözüm olabileceğini şu şekilde ifade etmişlerdir: Ö3 "Yani çocuğun hazırbulunuşluk düzeyine göre anasınıfina veya ilkokula yönlendirmek lazım.", V2 "Mutlaka anasinifina gitmeli. Eğer gitmiş olsaydı daha da açılacaktı. Arkadaşlar ile daha iyi anlaşacaktı. Oğlanları anasınıfına göndermiştim, ilkokulda bundan daha iyiydi.", Ö5 "Okul öncesi eğitim almış olmalı...ısrarla ilkokula başlatan olursa bir kere mutlaka evde eline kağıt kalem verin, eliyle yırtsın gazete kağıtlarını, makas kullansin, en azından hamurla oynasın, o bilekleri güçlensin, mandal takma çıkarma, kavanoz açma kapama, el kaslarmı güçlendirecek çalışmalar yapmaların öneriyorum En azından o büyük olanlara yetişsin diye. Çünkü yorulup sıkılınca çocuk kendini kapatıyor öğrenmeye de."

Katılımcı öğretmenler ayrıca veli bilinçlendirme çalışmalarının $(f=2)$ önemli olduğunu vurgulamışlardır. Bununla ilgili olarak Ö3 “Bir kere velilerin bilinçli olması lazım. 1. sımıfa gitmesi gereken öğrencilerin belirli yaş araliklarn var. Verebilir de vermeyebilir de veya doktor raporu alarak erteletebilir. Veliler bunu çok düşünmüyorlar. Dediğim gibi anasınıfına göndermemek için 1. sinıfa gönderiyorlar ya da bir arkadaşı ya da yaşıtı okula gittiğinde geri kalmasin diye gönderiyorlar.",Ö4 "Bence öncelikle veliyi bilgilendirmek gerekir. Her şey velide bitiyor. Veli bilinçlendirilmeli. Çocuğu nereye götürürsen gider. Okula gitme desen gitmez, git desen gider. Bence öncelikle bu konuda veli çözülmeli. Velinin kafasinda neden okula gönderiyorum sorusunun cevabı öğrenilmeli. Çocuğundan kurtulmak için mi? Yoksa çocuğunun çok iyi eğitim alması için mi? Onun sebebi öğrenilmeli bence." şeklinde ifade etmişlerdir. 
Katılımcı veliler oyun derslerinin sayısının arttırılabileceğini şu şekilde ifade etmişlerdir: V3 "Şimdi şöyle, bizim öğretmenimiz de yaptı bir ara ama çok fazla yapmadi. Dersin bir tanesini oyun dersi yapabilir mesela. Bu çocuklara eğlence dersi yapabilir. Çocuklarm daha çok oyun oynamasını sağlayabilir. Çünkü çocuklar oyun okulundan çıkıp ders okuluna girdiğinde çocuklar biraz sıkıntıya girebiliyor. Tamamen sıkıntıya girmeseller de bir yerde sıkılabiliyorlar. 6 dersten bir tanesini oyun dersi yapsalar mesela. Hamurdur, resimdir, isteyen neyi oynamak istiyorsa serbest olarak öyle bir şey yapilabilirdi.", V4 "Daha çok oyun oynatılabilir. Aslında böyle bir sisteme geçiriyorsa o zaman herkese zorunlu tutup, aynı yaş grubu çocukları bir sinıfa konulup, herkesin kendi düzeyinde bir sınıf yapılabilir. Ama şu an sınıflarda biri 2012 doğumluyken diğeri 2010 doğumlu. 2 yaş fark var." Öğretmenlerden Ö2 ise oyun derslerinin önemi ile ilgili "Oyun aktivite dersleri konmuştu, hakkında değgişiklik yapılmıştı ama sonra tekrar değiştiği için bir daha müfredat yenilendi. Şu an 1. sinıf müfredatı zaten çok ă̆ır değil 1.sınffta her zaman oyun dersi var, serbest etkinlik var. O da çok önemli çocuklar onlarl çok seviyor. Böyle etkinlikler yapınca başarma duygusu oluşuyor onlarda da ya da etkinliği yaptp astı̆̆gmızda sergilediğimiz de çok hoşuna gidiyor, ben yapabiliyorum duygusu oluşuyor... çoğu öğretmen o derslerde bile ders işlemeyi tercih ediyor. Aslında o çocuklarm hakkı oyun oynamak ama zaman yetmiyor okuma yazmaya geç geçiyor. Becerilerinden dolayl, mesela yazacak 3 saatte yazamıyor bu yüzden bir saat daha atıyor oyun derslerine çıkartmıyor. Aslında çıkartsalar daha çok faydalı olacak." görüşünü belirtmiştir.

Katılımclardan Ö4, Ö2'nin aksine müfredatın ağır olduğunu “Bir de şöyle; bizim eğitim sistemimiz hemen boğuyor derse. Toplama veriyoruz, çıkarma veriyoruz, çarpma bölme... o yüzden çocuk zorlanıyor. Kesinlikle oyun çă̆ı tam atlatılmalı öyle geçilmeli derslere."şeklinde ifade etmiştir.

Katılımcı velilerden V5 ise sınıf mevcutlarının azaltılması yönünde çözüm önerisini şu şekilde belirtmiştir: "Bence ilk başta sınıfların mevcudu az olması gerekiyor. Bizim okulumuzda 40-45 kişi. O şekilde öğretmenlerin biraz daha ilgili olması gerekiyor. Biz okulda bunu yaşıyoruz. Öğretmenler okuma bilmeyen ya da geride olan çocukları siralarm en arkasina koyup; bu zaten bilmiyor, aile de ilgisiz diye ilgilenmediğini görüyoruz. Tabii ki burada bize de ailelere de çok büyük iş düşüyor. Sürekli çocuğu okutmak gerekiyor. Bizim kendi öğretmenimizin de bizden tek istediği, sürekli okusun. Başka yapacak hiçbir şey yok diyor. Çünkü harfleri hala karıştırıyor." 


\section{Sonuç ve Tartışma}

Araştırmadan elde edilen bulgular değerlendirildiğinde aşağıdaki sonuçlara ulaşılmıştır:

İlkokula erken yaşta okula başlayan öğrencilerin sınıfta geri kaldıkları ve ilerleyen dönemde de bu açı̆̆ı kapatamadıkları sonucuna ulaşılmıştır. Benzer şekilde Şahin ve Güzel (2018) 4+4+4 eğitim sisteminin bir getirisi olarak ilkokula erken yaşta başlayan öğrencilerin bir çok alanda başarısız oldukları sonucuna ulaşılmıştır. Duran(2013), on altı haftalık oryantasyon eğitimi sonunda da ilkokula erken yaşta okula başlayan öğrencilerin çoğunun becerilerindeki yetersizliklerinin devam ettiğini bildirmiştir. Arı (2014) da okula başlama yaşının beş yaşa düşürülmesiyle farklı hazır bulunuşluğu farklı düzeyde okula başlayan öğrencilerin aralarındaki seviyenin de zamanla açıldığını tespit etmiştir. Bloom (1998)'a göre ilk öğrenme ünitesinde, tamamlanmadan bırakılan öğrenme eksiklikleri ikinci ünitede daha büyük sayıda tamamlanmamış öğrenme eksikliklerine dönüşür ve bu eksiklikler daha sonra gelen öğrenmelerde daha da artması kaçınılmazdır (akt; Arı, 2014).

Araştırma ile 8 aydan 24 aya kadar farklı yaş grubu çocukların aynı sinıfta eğitim görmelerinin öğrenme sürecine olumsuz etki ettiği sonucuna ulaşılmıştır. Benzer şekilde Şahin ve Güzel (2018) 2012-2013 eğitim öğretim yılında ilkokula başlayan öğrencilerin yaşlarının dağılımının 60 ay ile 84 ay arasında değiştiği ve ilkokula 69 aydan önce başlayan öğrencilerin kendilerinden yaşça büyük okula başlayanlara göre Türkçe, Matematik ve Hayat Bilgisi derslerinde geri kaldıkları sonuçlarına ulaşmışlardır. Iş̧ıoğlu, Erdoğan ve Şimşek (2014), aynı sınıfta aralarında yaş farkı olan öğrencilerin okula uyumu konusunda veli ve öğretmenler ile yaptıkları çalışma sonucunda gelişim düzeyleri arasında fark bulunan öğrencilerin aynı sınıfta eğitim almalarının okula uyum sağlamasını olumsuz yönde etkilediğini tespit etmişlerdir. Memişoğlu ve İsmetoğlu (2013), aynı sınıfta eğitim gören farklı yaşlardaki öğrencilerin çeşitli sorunlara neden olduğunu belirttiği, okul yöneticilerinin $4+4+4$ olarak değişen eğitim sistemi konusunda deneyimlerini incelediği araştırması da araştırmanın bu sonucunu desteklemektedir. Benzer olarak Gündüz ve Özarslan (2017) çalışmasında 72-84 aylık çocukların akademik olarak, okul olgunluğuna erişememiş 60-71 aylık çocuklardan daha hazır 
oldukları sonucuna ulaşılmıştır. Calp (2014) ise ay olarak aralarında fark olan çocukların derse katılımının benzer olduğu, ancak okuma becerileri puanlarının yaşça büyük olan çocukların lehine olduğunu tespit etmiştir. Canbulat (2017) okula uyum ve okula hazır bulunuşluk açısından 60-65 ay arasındaki öğrencilerin 66 ay ve üstü yaştaki öğrencilere göre anlamlı düzeyde daha geride olduklarını ifade etmiştir. Benzer olarak Bayat (2015) yaptığı çalışma sonucunda öğretmenlerin, okul olgunluğu seviyesi ve ilk okuma yazma öğrenimi açısından 60-66 aylık öğrenrencilerle büyük yaş grubu öğrencilerinin aynı sınıfta eğitim almalarının çeşitli güçlüklere sebep olduğu sonucuna ulaşmıştır. Öztürk (2013) farklı takvim yaşındaki öğrencilerin algılama farklılıkları nedeniyle öğretmenlerin 60-66 aylık öğrenciler ile iletişim kurmada sıkıntı yaşadıklarını ve eğitim öğretim sürecinde aksamalar olduğunu belirtmiştir.

Farklı yaş grubu öğrencilerin aynı sınıflarda bulunması ile ilgili olarak büyük yaş grubu öğrencilerin küçük yaş grubu öğrencileri ezdiği sonuçlarına ulaşılmıştır. Araştırmanın bu sonucunu destekleyen Kahramanoğlu ve arkadaşları (2014), küçük yaş öğrencilerin yaşça büyük sınıf arkadaşları tarafından psikolojik baskıya maruz kaldıklarını belirtilmiştir. Benzer olarak Arı (2014) farklı yaş çocuklarının gruplaştığı ve küçük yaşların dışlanıp ezildiği, oyunlara alınmadıkları, iletişim kurmada sorunlar görüldüğü ve yaşanılan anlaşmazlıklar sonucu kavgalar olduğu sonuçlarına ulaşmıştır.

İlkokula erken yaşta başlayan öğrencilerde en çok psikomotor ve sosyal duygusal alanda problemler yaşandığı sonucuna ulaşılmıştır. Bu öğrencilerin el kaslarının gelişmediği, arkadaşlık kurmada ve anne babadan kopamama sorunları yaşadıkları tespit edilmiştir. Benzer olarak Koçyiğit'in (2009) ve Ülkü'nün (2007), yaptıkları araştırmalarında duygusal gelişim açısından okula başlamada en sık görülen problemin annebabadan ayrılamama sonucu araştırmayı destekler niteliktedir. Alanyazında yapılan araştırma sonuçları incelendiğinde ilkokula erken yaşta başlayan çocukların, kalemi doğru tutma, makas kullanma, boyama gibi el-göz koordinasyonu gerektiren becerilerinin gelişmediği (Bağçeli vd., 2013; Şentürk,2016), parmak kaslarının yeterince gelişmediği (Boz ve Yıldırım, 2014; Kahramanoğlu vd., 2014), çabuk yoruldukları (Arı, 2014; Bayat 2015; Gündüz ve Çalışkan,2013; Özenç ve Çekirdekçi, 2013), sosyal ilişki sorunları yaşadıkları (Kerimoğlu, 2014) araştırma sonuçlarıyla 
örtüşmektedir. İlkokula erken yaşta başlayan öğrencilerde bilişsel gelişim açısından bireysel farklılıklar söz konusu olmakla birlikte anlamada sıkıntı yaşadıkları ya da anlasalar bile el kasları gelişmediği için yapamadıkları yönünde sonuçlara ulaşılmıştır. Bayat (2015)'ın yaptığı çalışmada, 60-66 aylık okula başlayan öğrencilerin bilişsel olgunluk düzeylerinin; sosyal, motor, duyuşsal olgunluk düzeylerinden daha yeterli düzeyde olması araştırmanın bu sonucunu desteklemektedir. Bazı araştırmacılar ise 60-66 aylık öğrencilerin ifade edilen durumları (Kahramanoğlu vd., 2014)ve okuduğunu anlamada (Tutal ve Oral, 2015)sorun yaşadıklarını; algılama, anlama, hatırlama gibi zihinsel süreçlerde yetersiz (Şentürk, 2016) ve bilişsel gelişim olarak daha geride (Öztürk, 2013) olduklarını belirtmişlerdir.

İlkokula erken yaşta başlayan öğrencilerin, çeşitli uyum sorunları yaşadıkları belirlenmiş ancak velilerden ilkokul mezunu olanlar uyum sorunu yaşamadıklarını ifade etmişlerdir. Can (2009) velilerin eğitim seviyelerine paralel olarak çocuklarının eğitimi ile ilgilenme sıklıklarının arttığı; Ünver ve arkadaşları (2015) ise eğitim düzeyi yüksek anne babaların, çocuklarını ilkokula daha geç başlattıklarını tespit etmişlerdir. Bu araştırmalar, çocuğu ilkokula erken yaşta başlayan ilkokul mezunu velilerin çocuklarının uyum sorunları yaşasalar da fark edemeyecekleri sonucunu düşündürmektedir. Araştırma sonucunda en fazla yaşanan uyum sorunlarının alt ıslatma, çekingenlik, çabuk küsme, utangaçlık, saldırganlık ve okul fobisi olduğu görülmüştür. Bunların dışında okuldan kaçma, tırnak yeme, başarısızlık korkusu, takıntı ve iletişim sorunları da araştırma sonucu ulaşılan bulgulardandır. Araştırmacılar da benzer olarak erken yaşta okula başlayan çocuklarda görülen uyum problemlerini;uzun süre sınıfta kalmaktan sıkılma, disiplin sorunları, ağlama, küsme, saldırganlık(Şentürk, 2016);huzursuzluk, kaygı, utangaçlık (Kerimoğlu, 2014); anneden kopamama, çekingen davranma (Yılmaz vd., 2013); okuldan uzaklaşma (Bağçeli vd., 2013) olarak sıralamışlardır.Kahramanoğlu ve arkadaşları (2014)ise erken yaşta ilkokula başlayan öğrencilerin okulda yaşayabileceği olası altına kaçırma, temizliğini yapamama gibi durumlarda, utanabilecekleri sonucuna ulaşmışlardır.

Araştırma sonuçlarına göre öğrencilerin akademik başarıları öğretmenler ve veliler tarafından farklı değerlendirilmektedir. Araştırmaya 
katılan velilerin el kasları zayıf olduğu için öğrencinin başarısız olduğunu düşünmeleri, başarıyı sadece psikomotor gelişimle ilişkilendirdiklerini göstermektedir. Ancak öğretmenler başarıyı farklı ölçütlere göre değerlendirmektedirler. Araştırmaya katılan öğretmenlere göre farklı gelişim alanlarında yaşanan sorunlardan dolayı sınıftan geri kaldığ için başarısız oldukları sonucuna ulaşılmıştır. Dersleri anlayamadığı, anlasa da el kaslarının zayıf olmasından ötürü yapamadığı ve kendini ifade edemediği için başarısız oldukları sonuçlarına ulaşılmıştır. Ayrıca erken yaşta okula başlayan bazı çocukların başaramayacaklarına inandıkları ve başarısızlığı kabullendikleri de tespit edilmiştir. Benzer olarak Şentürk (2016), ilkokula erken yaşta başlayan çocukların kendini yetersiz görme, özgüven kaybı yaşadıkları; Kerimoğlu (2014), akademik becerilerde yetersizlik, olumsuz akademik benlik algısı ve akademik alanlara ilgisizlik sonucu örgün eğitim sisteminin gerektirdiği becerilerde yetersiz olduklarını belirtmişlerdir. Öğrencilerin başardıkları öğrenmeler yerine başarısızlıklarının üzerinde durulması, onların akademik benliklerinin düşük olmasına ve öz güven sorunlarına neden olur(Çelenk, 2013). Kılıççı (1992) ise okula başlama ile kendinden beklenenleri yerine getirebilmek için büyük güç harcayan çocukların sürekli başarısızlık yaşamalarının, çocuğun önceden geliştirdiği öz saygısını olumsuz etkilediğini belirtmektedir(akt; Arı, 2014).

Araştırmada öğrencilerin yaşı arttıkça olgunlaşma ve buna bağlı olarak hazırbulunuşluk düzeyi artacağından başarının da artacağı sonucu; Başar (2001) Canbulat (2017), Gündüz ve Çalışkan (2013) ve Gündüz ve Özarslan (2017)yaptıkları araştırma sonuçlarıyla örtüşmektedir. Benzer olarak Langer, Kalk ve Searls (1984) tarafından 9 yaşında okula devam eden öğrencilerin başarılarının incelendiği araştırmada, okula yaşı büyük başlayanların yaşı küçük olanlara göre daha başarılı oldukları sonucuna ulaşılmıştır (akt;Tutal ve Oral, 2015).

İlkokula erken yaşta başlayan öğrencilerin davranış ve gelişimsel olarak ilkokula başlamak için hazır olmadıkları sonuçlarına ulaşılmıştır. Bununla ilgili olarak el kaslarının gelişmemiş olması, sıkılması, ağlaması, okul kuralları ve disiplinine uyum sağlayamaması gibi çeşitli etkenlerin ilkokula hazırbulunuşluğu etkilediği sonucuna ulaşılmıştır. Yapılan araştırmalar, ilkokula erken yaşta başlayan çocukların okula başlamak için gerekli hazırbulunuşluk düzeyinde olmadıkları sonucunu 
desteklemektedir (Arı, 2014; Aybek ve Aslan, 2015; Başar, 2013; Boz ve Yıldırım, 2014; Cerit vd., 2014; Gündüz ve Özarslan, 2017; Işıkoğlu vd., 2014; Özenç ve Çekirdekçi, 2013; Uzun ve Alat, 2014; Yangın, 2009). Ancak araştırmaya katılan velilerin, çocukların hevesli, istekli oldukları ve evde sıkıldıkları için okula başlamaya hazır olduklarını düşünmeleri, ilkokula hazırbulunuşluğu sadece sosyal duygusal gelişimle ilişkilendirdiklerini göstermektedir.

Araştırma ile ilkokula erken yaşta başlayan öğrencilerde görülen sorunlarla baş etmede en çok öğrenciyi konuşup rahatlatma, el kaslarını geliştirici etkinlikler ve oyun etkinliklerinin uygulandığı sonuçlarına ulaşılmıştır. Araştırmanin bu sonucunu destekleyici nitelikte Boz ve Yıldırım (2014), öğretmenlerin derslerde sıkça oyun ve şarkılara yer verdiği; Öztürk (2013) de öğretmenlerin bol miktarda görsel-işitsel materyaller kullandığı, sınıfı gruplara ayırdığı, tekerlemeler öğrettiği ve el kaslarının gelişimini destekleyici elden tutup yazdırdığı, kılavuz çizgili parmak çalışmaları yaptırdığı ve kesme, boyama, yapıştırma etkinlikleri uyguladığı sonuçlarına ulaşmışlardır. Araştırmaya katılan öğretmenler ile velilerin hedeflenen düzeyde işbirliği yapılamadığı sonucunda öğretmenlerin rehberlik servisinden yaralandıkları sonucuna ulaşılmıştır. Benzer olarak Aybek ve Aslan (2015)'ın yaptıkları çalışmadaöğretmenler erken yaşta okula başlayan öğrenci velilerinin ilgisiz ve bilgisiz olduğu; Buldu ve Er (2016) ise öğretmenlerle aileler arasında yetersiz işbirliği olduğu sonuçlarına ulaşılmışlardır. Kahramanoğlu, Tiryaki ve Canpolat (2014)ise erken yaşta okula başlayan öğrencilerden, aile ilgisi yüksek olan öğrencilerin olumlu yönde bireysel farklılık gösterdiğini ifade etmiştir. Yapılan araştırmalar sonucu aile tutumu ile çocukların hazırbulunuşluğu arasında güçlü bir ilişki olduğu tespit edilmiştir(Belfield ve Garcia, 2014).

İlkokula erken yaşta başlayan öğrencilerde görülen sorunlarla baş etmede kullanılan yöntemlerden biri olan uyum haftası etkinliklerinin erken yaşta okula başlayan öğrenciler açısından yararlı olduğu sonuçlarına ulaşılmıştır. Keskinkılıç (2002), yapılan okula uyum programlarının ilkokula başlayan çocukların tanınması açısından çok önemli olduğunu belirtmiştir. Araştırma sonuçlarından farklı olarak Arı (2014) okula yeni başlayan çocuklara uygulanan okula uyum programlarının okul öncesi eğitim alan veya 66 aydan büyük çocuklar açısından çok 
sıkıc olduğunu; daha önce okul öncesi eğitim almayan veya ay olarak küçük olan öğrenciler açısından zorlayıcı ve yorucu olduğunu ifade etmiştir. Araştırmanın bulgularından biri de öğretmenlerin ilkokula erken yaşta başlayan ancak alışamayan çocukları anasınıfına yönlendirmeleridir. İlkokula erken yaşta başlayan öğrencilerde görülen sorunlarla ilgili olarak velilerin, çocuklarına evde dersleri tekrar etmelerine yardımcı oldukları ancak genellikle çocukları zorlamadıkları sonuçlarına ulaşılmıştır.

Öğretmenlerin kıdem yılı erken yaşta ilkokula başlayan çocukların uyum sorunu yaşamalarına ilişkin görüşlerinde farklılık göstermektedir. Kıdem yılı düşük olan öğretmenler okulöncesi eğitim alan çocukların uyum sorunu yaşamadıklarını belirtirken; kıdem yılı yüksek olan öğretmenler özellikle disiplin ve sınıf kurallarına uyma sorunları yaşadıklarını ifade etmişlerdir. Araştırmanın bu sonucundan farklı olarak Gündüz ve Özarslan (2017) tecrübeli öğretmenlerin daha az tecrübeye sahip öğretmenlere göre çocuklarda görülen uyum sorunlarına daha olgun olarak yaklaştıkları sonucuna ulaşmıştır.

Araştırma sonucunda çocukların ilkokula erken başlatılmaması ve okulöncesi eğitim almaları gerektiği tüm öğretmenler tarafından ifade edilmiştir. Okul öncesi eğitimi alan çocukların el kasları gelişiminin okul öncesi eğitim almayanlara göre daha iyi düzeyde oldukları ve uyum sürecini daha kolay atlattıkları araştırma sonucu elde edilen bulgulardandır. Birçok çalışma sonucunda da okul öncesi eğitimin, okula hazır bulunuşluğa olumlu etki ettiği belirlenmiştir (Cinkılıç, 2009; Erkan ve Kırca, 2010; Özkesemen, 2008; Teke, 2010).Okul öncesi eğitim alan öğrencilerinokula uyum, (Canbulat, 2017; Esaspehlivan, 2006; Yoleri ve Tanış, 2014),ilk okuma-yazma, okuduğunu anlama başarıları, dikte ve yazma becerisi (Damarlı Oçak, 2007; Obalar, 2009; Tutal ve Oral, 2015; Yılmaz ve Sığırtmaç, 2008; Bulut, 2010; Çelenk, 2008) okul öncesi eğitim almayan öğrencilere göre daha yüksek olduğu sonuçları araştırma sonuçları ile örtüşmektedir. Kazu ve Eroğlu (2012) öğretim elemanlarının görüşlerini aldıkları çalışma sonucunda, yeni eğitim sisteminin olumsuzluğu olarak öğrencilerin ilkokula okul öncesi eğitim almadan başlamaları olduğunu tespit etmiştir. Dünya geneline bakıldığında öğrencilerin ilkokula erken yaşta başlatılması yerine okul öncesi eğitimin öneminin arttı̆̆1 bilinmektedir. Ülkelerin gelişmişlikleri arttıkça okul 
öncesi eğitimde kalite ve verimlilik çalışmaları yapılmakta ve okul öncesi eğitimden faydalanma düzeyi artmaktadır (Erkan ve Kırca, 2010).

Araştırma ile ilkokula erken yaşta başlayan öğrencilerin yaşadıkları mevcut sorunların çözümüne ilişkin velilerin bilinçlendirilmesi gerektiği sonuçlarına ulaşılmıştır. Benzer olarak Kartal (2013), yaptığı çalışmasında okul öncesi eğitimin arttırılması ve bu konuda ailelere bilinçlendirme çalışmalarının yapılması üzerinde durmuştur. İlkokula erken yaşta başlayan öğrencilerin yaşadıkları mevcut sorunların çözümüne ilişkin sonuçlar; oyun ve eğlence derslerinin çoğaltılması, aynı yaş grubu çocukların aynı sınıfı paylaşmaları ve sınıf mevcutlarının azaltılması şeklinde sıralanmaktadır. Sınıf mevcudu; öğrencilerin gelişimlerinin takibi (Boz ve Yıldırım, 2014); öğrencilerin de okuma yazma becerilerinin gelişmesi bakımından etkilidir (Pedder, 2006). Araştırmanın diğer bir sonucu ise öğretmenler tarafından müfredatın hafifletilmesi gerektiğidir. Bununla ilgili olarak Şentürk (2016), ders kitaplarının erken yaşta okula başlayan öğrencilere uygun hazırlanmadığı ve mevcut programı yetiştirmekte zorlanıldığı sonucuna ulaşmıştır. Benzer olarak Bayat (2015) programın ve içeriğin bu yaş gurubu için uygun olmadığını, programın bu yaş grubuna göre hafifletilmesi gerektiğini belirtmiştir. ÜnalPeker (2013), yenilenen ilkokul sınıf programını incelediği araştırmasında çocukların okula uyum sağlamasında, gereken yeterlilikleri kazanmasında ve okulun sevilmesinde birinci sinıf programinn yeterli olmadığını belirtmiştir. Aybek ve Aslan (2015) da öğretim programlarında yer alan kazanımların 5 yaş grubu çocukların gelişim özellikleri dikkate alınarak hazırlanmadığı, bu nedenle bu öğrencilerin kazanımlara ulaşamadığını ifade etmişlerdir.

Araştırmada öğretmenler tarafından çocukların ilkokula kesinlikle erken başlatılmaması gerektiği; yaşına bağlı olarak sınıftan geri kaldıkları ve başarısız oldukları; eğitim düzeyi yüksek velilerin çocuğunu erken yaşta ilkokula başlattıkları için pişman oldukları ve zorlandıkları sonuçlarına ulaşılmıştır.

\section{Öneriler}

İlkokula kayıt yaşı, ilkokula başlamak için yeterli hazırbulunuşluğun kazanılmış olması ve gelişim özellikleri açısından 72-84 ayolarak düzen- 
lenmelidir. İlkokula erken yaşta başlayan öğrencilerin yaşadıkları uyum sorunlarının çözümüne ilişkin olarak okulöncesi eğitim zorunlu hale getirilmelidir.

Milli Eğitim Bakanlığı ve Sağlık Bakanlığı işbirliği çerçevesinde 60-66 ay çocuklarının gelişimsel özellikleri ve okul hazırbulunuşluğu ile ilgili veli bilinçlendirme çalışmaları yapılmalıdır. Ayrıca ilkokul sınıf öğretmenlerine ve okulöncesi öğretmenlerine ilkokula hazırbulunuşluk, uyum sorunları ve çözümlerine ilişkin eğitim verilmelidir.

60-66 aylık çocuklara yönelik ilkokula başlamadan önce okul olgunluğu testi uygulanması zorunlu hale getirilebilir. Farklı olarak ilkokula kaydı yapılan öğrencilerin sınıfları oluşturulurken okul olgunluğu testi sonuçlarına göre aralarında fazla seviye farkı olmayan öğrencilerin bir arada bulunması okulun ilk yıllarında önerilir.

Araştırmacılara yönelik olarak ilkokula erken yaşta başlayan öğrencilerin gelişim özellikleri, hazırbulunuşluğu, akademik başarıları ve uyum sorunları ile çözümlerine ilişkin gözlem kayıtları, anekdot vb. çeşitli veri toplama araçları ile araştırma yürütülebilir. Araştırma katılımcılarına okul yöneticileri ve öğrenciler dahil edilebilir. Öğrencilerin cinsiyet, tek çocuk olup olmama, aile yapısı ve sosyo-ekonomik düzeyi değişkenlerine göre okula uyum süreci incelenebilir. 


\title{
EXTENDED ABSTRACT
}

\section{Adaptation Process of Students Who Start Primary School at an Early Age and Their Problems on the Context of Academic Success}

\author{
Ali Özdemir - Şifanur Battal \\ Marmara University
}

Turkey in the 2012-2013 academic year has switched to $4+4+4$ education system. In line with this education system, according to Primary Education Institutions of Ministry of National Education Regulation, which was published in 28360 numbered circular and 21.7.2012 dated Official Newspaper, and according to the request of parents, children being between 60-66 months can be enrolled in a primary school (Milli Eğitim Bakanlığı [MEB], 2012). Prior to this regulation, children who completed 72 months as of 31 December were being enrolled in a primary school. When that the age of enrollment in primary school is lowered by this regulation and that starting the primary school is dependent on the request of the parents are taken into consideration in terms of the periods of development, it is seen that this regulation has caused the situation that children who are not ready for primary school start primary school. When the studies on this subject were examined, it was stated that the age of enrollment in school from 5.9 to 6.3 years of age gives the best results in terms of maturity and that it is appropriate the children start school at these ages(Sharp, 1998, Akt; Ülkü, 2007). In addition to taking the calendar age into consideration in the subject of the necessity that children should start or not start school, their readiness related to starting to school in the domains of behavior development with levels of physical, psychomotor, mental, social and emotional development should be taken into consideration (Aykaç et al., 2014; Calp, 2014; Denham 2006; Howes et al., 2008; Snow 2006). With the start of school, a period of adaptation, which may have an impact on children's lives even later, begins. In order to successfully overcome this process, children need to have reached the level of starting primary school in terms of 
their skills in different domains of development. The arrangements made by the Ministry of National Education on the basis of the calendar age to start school ignore physiological, mental, social-emotional and environmental factors (Oktay, 2010) affecting the primary school readiness; and make think that it prepares the ground for various adaptation problems and academic failure in the way.

The study is important in terms of examined in different subdimensions the adaptation problems and the academic success of the students who started school at an early age with the request of their parents, which has come into force in the 2012-2013 academic year. With this research, students', who started school at an early age and are still continuing their education at primary school level, problems which they have in the school and at home because of their features of development, and their readiness levels' effect on their learning processes and their academic success were determined and evaluated. The findings obtained from the study are important in terms of improving the process by determining the current situation related to the adaptation problems caused by the decrease in school starting age and offering solutions to the policy-makers.

The aim of the study is that the adaptation problems and academic success of the students (60-66 months) who started to primary school with the request of parents are evaluated according to the views of parents and teachers and is to make concrete determinations which can produce suggestions to policy-makers.

In this study, phenomenological design, which is a qualitative research method, was used.It focuses on phenomena that are noticed but are not known in detail (Creswell, 2015). Participants were selected by using purposive sampling method. One of these methods is the criterion sampling method that meets some of the predetermined important criteria in this context (Patton, 2014). Criteria for selecting participants are that she/he worked as a classroom teacher at primary school level in the 2017-2018 academic year, she/he had students, starting to primary school at an early age, in her/his classroom and she/he worked in the academic year before the change of decreasing the age of enrollment at primary school. Participants consist of 5 volunteer teachers working in the schools in Pendik, İstanbul, and 5 volunteer students' (who started 
school at an early age in the schools which the volunteer teachers work) parents.

The data were collected by a semi-structured interview form prepared by the researcher and improved by field experts. The descriptive analysis method was used to analyze the data. In order to increase the validity and reliability of the research, quotations that reveal the views of the participants are frequently included. Within the scope of the study, the participants' opinions were gathered around 7 general themes: the application of starting primary school at an early age, developmental characteristics of the students starting primary school at an early age, their adaptation process, their academic success, their readiness levels and methods used in coping with the problems seen in students starting primary school at an early age and solution suggestions. When the findings related to the application of starting primary school at an early age were examined, it was found that the most frequently repetitive data were the difficulty in writing and falling behind in the class $(f=5)$. It was concluded that the students who started primary school at an early age experienced mostly psychomotor and social-emotional problems. It was found that these students' hand-muscles did not develop, had problems with making friends and related to not being with parents.

It was determined that the most common adaptation problems in the adaptation process of the students who started primary school at an early age were bedwetting, timidity, being easily offended, shyness, aggression and school phobia. The primary school graduates among the participant parents stated that they did not experience compliance problems. In this context, Ünver et al. (2015) found that the more the level of parents' education increases, the more they make their children start primary school at a later age.

When the research findings were evaluated, most of the participants $(f=8)$, the whole of the teachers, stated that academic success and age were directly proportional to each other. Students' academic success is evaluated differently by teachers and parents. The fact that the parents who participated in the study thought that the student was unsuccessful because of the weakness of their hand-muscles shows that they associate success only with psychomotor development. However, teachers evaluate success according to different criteria. 
The majority of the participants stated that the children who started primary school at an early age were not ready for primary school and their level of readiness was low. At the end of the research, it was observed that children were eager and willing to start school and were bored at home. Parents considered these situations as a readiness criterion needed to start school. When the findings related to the methods used to cope with the problems encountered in the students who started primary school at an early age were examined, the whole of the teachers stated that they met and cooperated with the parents; and the parents also stated that they were trying to make him/her relax by talking with the child. The results of the research revealed that making the student relax by talking with the student, activities developing hand-muscles and game activities were applied mostly in coping with the problems encountered in the students who started primary school at an early.

It was concluded by the research that the education of children of different age groups, from 8 months to 24 months, in the same class had a negative impact on the learning process. However, it was found that the hand-muscles development of the children who had pre-school education was better than the ones who did not have pre-school education, and the children who had pre-school education got over the adaptation process more easily than the ones who did not have pre-school education. Şahin and Güzel (2018) reached the results that the distribution of the ages of the students who started primary school in the 2012-2013 academic year ranged from 60 months to 84 months, and the students who started primary school before 69 months fell behind in Turkish, Mathematics and Social Studies courses when compared to the ones starting at a later age.

As a result of the research, it was stated by all teachers that children should not start primary school at an early age and they should take preschool education. It was concluded that due to the developmental characteristics of the children who started primary school at an early age, their readiness levels were inadequate, that they had various adaptation problems and depending on it, their academic success was low. In this context, practices, such as that the students who attend the first year of primary education are organized in the way in which they will be in the same month range in terms of their developmental characteristics, the 
expansion of pre-school education and the increase of physical activity courses in primary education, were suggested by the participants for the solutions of the problems experienced.

\section{Kaynakça / References}

Akyol, H. (2006). Türkçe ilk okuma yazma öğretimi. Ankara: Pegem A Yayincilik.

Arı, A. (2014). İlkokul birinci sınıfa başlama yaşına ilişkin öğretmen görüşleri. Kuram ve Uygulamada Eğitim Bilimleri, 14(3), 1031-1047.

Aybek, B. ve Aslan, S. (2015). İlkokul birinci sınıf öğretmenlerinin 4+4+4 kesintili zorunlu eğitim sisteminde yaşamış oldukları sorunlara ve çözüm önerilerine yönelik görüşlerinin incelenmesi. Pegem Ĕgitim ve Öğretim Dergisi, 5(3), 327-346

Aykaç, N., Kabaran, H., Atar, E. ve Bilgin, H. (2014). İlkokul 1. Sınıf öğrencilerinin $4+4+4$ uygulaması sonucunda yaşadıkları sorunların öğretmen görüşlerine dayalı olarak değerlendirilmesi:Muğla ili örneği. International Periodical For The Languages, Literature and History of Turkish or Turkic 9 (2), 335-348.

Bağçeli K., P. ve Başal, H. A. (2013). Okula hazırbulunuşluğu değerlendirme testinin uyarlama çalışması. International Journal of Social Science, 6(1), 889-911.

Başar, E. (2001). Genel öğretim yöntemleri. Samsun: Kardeşler Ofset ve Matbaa

Başar, M. (2013). 60-66 ay aralığında ilkokula başlayan öğrencilerin kişisel öz bakım ve ilkokuma-yazma becerilerinin öğretmen görüşlerine göre değerlendirilmesi. International Periodical For The Languages, Literature and History of Turkish or Turkic, 8 (8), 241-252.

Bayat, S. (2015). İlkokuma yazma öğretiminde 60-66 aylık çocuklar ile ilgili yaşanan güçlüklere ilişkin öğretmen görüşleri. Uluslararası Türk Ĕ̆itim Bilimleri Dergisi, 4, 172-185

Belfield, C. ve Garcia, E. (2014). Parental notions of school readiness: How have they changed and has preschool made a difference? The Journal of Educational Research, 107, 138-151. 
Boz, T. ve Yıldırım, A. (2014). 4+ 4+ 4 eğitim sisteminde birinci sınıf öğretmenlerinin karşılaştığı zorluklar. Başkent University Journal of Education, 1(2), 54-65.

Buldu, M. ve Er, S. (2016). Okula hazırbulunuşluk ve okula başlama yaşı: Türk öğretmen ve ailelerin yeni eğitim politikası üzerine görüş ve deneyimleri. Ĕ̆itim ve Bilim, Erken Görünüm, 1-18.

Bulut, A.K. (2010). Eğitimde ses temelli cümle yöntemi uygulanan öğrencilerin okuma yazmaya geçişlerinde etkili olan faktörlerin incelenmesi. Yayımlanmamış Yüksek Lisans Tezi, Kafkas Üniversitesi Sosyal Bilimler Enstitüsü, Kars.

Calp, M. (2014). Farklı yaş aralığındaki birinci sınıf öğrencilerinin okuma, yazma, kalem tutma, derse katılma ve akademik başarılarının karşılaştırılması. Ekev Akademi Dergisi, 60, 31-54.

Can, B. (2009). İlköğretim programını uygulanması Sürecine velilerin katılımları ve okula ilişkin tutumları. Yüksek Lisans Tezi, Eskisehir Osmangazi Üniversitesi Sosyal Bilimler Enstitüsü, Eskişehir.

Canbulat, T. (2017). Kesintili zorunlu eğitimden etkilenen ilkokul birinci sinif öğrencilerinin okula uyum ve okula hazir bulunuşluk düzeylerinin değerlendirilmesi. Kastamonu Ĕ̆itim Dergisi, 25(4), 1573-1586.

Cerit, Y., Akgün, N., Yıldız, K., ve Soysal, M. R. (2014). Yeni eğitim sisteminin $(4+4+4)$ uygulanmasında yaşanan sorunlar ve çözüm önerileri:Bolu il örneği. EğitimBilimleri Araştırmaları Dergisi, 4(1), 59-82, doi: 10.12973/jesr.2014.4os4a

Chan, W. L. (2011). Expectations for the transition from kindergarten to primary school amongst teachers:Parents and children. Early Child Development and Care, 182 (5), 639-664.

Cinkılıç, H. (2009). Okul öncesi eğitimin ilköğretim 1. Sınıföğrencilerinin okul olgunluğuna etkisinin incelenmesi. Yüksek Lisans Tezi, Selçuk Üniversitesi, Sosyal Bilimler Enstitüsü, Konya.

Creswell, J. (2015). Educational research: Planning, conducting, and evaluating quantitative and qualitative research. New York: Pearson

Çelenk, S. (2008). İlköğretim okulları birinci sınıf öğrencilerinin ilkokuma ve yazma öğretimine hazırlık düzeyleri. Abant İzet Baysal Üniversitesi Eğitim Fakültesi Dergisi, 8(1), 83-90. 
Çelenk, S.ve Baycan, D.(2013) Illkokuma yazma programı ve öğretimi Ankara: Eğiten Kitap.

Çelenk, S. (2006). Etkinlik temelli ilkokuma ve yazma öğretimi. Morpa Kültür Yayınları.

Damarlı, O. S. (2007). Ilköğretim birinci sinif öğrencilerinin dil gelişim düzeyleri ile okuma yazma başarisi arasindaki ilişki. Yayımlanmamış Yüksek Lisans Tezi, Marmara Üniversitesi Eğitim Bilimleri Enstitüsü, İstanbul.

Obalar, S. (2009). Ilköğretim birinci sinif öğrencilerinin ilk okuma yazma becerileri ile sosyal duygusal uyum ve zeka düzeyleri arasindaki ilişkinin incelenmesi. Yayımlanmamış Doktora Tezi, Marmara Üniversitesi Eğitim Bilimleri Enstitüsü, İstanbul.

Denham, S. (2006). Social-emotional competence as support for school readiness: What is it and how do we assess it? Early Education and Development, $17,57-89$.

Dinç, E., Uzun, C. ve Çoban, O. (2014). Eğitimde kademeler arası geçişle ilgili öğretmen görüşlerinin incelenmesi. Uşak Üniversitesi Sosyal Bilimler Dergisi, 7(3), 209-235.

Doğan, S., Kelleci, M., Sabancıoğulları, S. ve Aydın, D. (2008). Bir ilköğretim okulunda öğrenim gören çocuklarda ruhsal uyum sorunları. TSK Koruyucu HekimlikBülteni, 7(1), 47-52.

Doğan, S.B., Demir, S. ve Pınar, M.A. (2014). 4+4+4 yeni eğitim sistemi'nin yansımaları: Beşinci sınıflardaki eğitim-öğretim sürecinin branş öğretmenlerinin görüşleri doğrultusunda değerlendirilmesi. Gaziantep University Journal of Social Sciences, 13(1), $115-138$

Duran, E. (2013). İlkokula 60. ayında başlayan öğrencilerin yazı beceri gelişimlerinin incelenmesi. International Journal of Social Science 6 (2), 1075-1085.

Erden, M. ve Akman, Y. (2004). Eğitim psikolojisi:Gelişim-öğrenme-öğretme. Ankara: Arkadaş Yayınları.

Erkan, S. ve Kırca, A. (2010). Okul öncesi eğitimin ilköğretim birinci sınıf öğrencilerinin okula hazır bulunuşluklarına etkisinin incelenmesi. Hacettepe ÜniversitesiEğitim Fakültesi Dergisi, 38, 94-106.

Ersoy, A. F. (2016). Fenomenoloji. Egĭtimde nitel araștırma desenleri, A. Saban ve A. Ersoy (Ed.) içinde (s. 51-109 ). Ankara: Anı Yayıncılık. 
Esaspehlivan, M. (2006). Okul öncesi eğitim kurumuna gitmis ve gitmemis 78 ve 68 aylık çocukların okula hazır bulunusluklarının karsılastırılması. YayınlanmamısYüksek Lisans Tezi, Marmara Üniversitesi Eğitim Bilimleri Enstitüsü, İstanbul

Fabian, H. (2000). Small steps to starting school. International Journal of Early Years Education, 8(2), 141-153, doi: 10.1080/09669760050046183

Gündüz, F. ve Çalışkan, M. (2013). 60-66, 66-72, 72-84 aylık çocukların okul olgunluk ve okuma yazma becerilerini kazanma düzeylerinin incelenmesi. International Periodical ForThe Languages, Literatureand History of Turkish orTurkic 8 (8), 379-398.

Gündüz, H. B. ve Özarslan, N. (2017). Farklı yaş kategorilerinde ilkokula başlayan öğrencilerin okul olgunluğu ve öğretmen görüşlerine göre okula uyum problemleri. Abant İzet Baysal ÜniversitesiĔ̈itim Fakültesi Dergisi,17 (1), 212-230.

Güneş, F. (2000). Okuma-yazma öğretimi ve beyin teknolojisi. Ankara: Ocak Yayınları.

Howes, C., Burchinal, M., Pianta, R., Bryant, D., Early, D., Clifford, R. ve Barbarin, O. (2008). "Ready to learn? Children's pre-academic achievement in pre-kindergarten programs": Erratum. Early Childhood Research Quarterly, 23(3), 429-430

Isıkoğlu, E. N. ve Simşek, Z. C. (2014). Birinci sınıfa başlayan çocukların, velilerin ve öğretmenlerin okula uyumlarının incelenmesi. International Journal ofNew Trends in Arts, Sports \& Science Education, 3(2), $62-70$.

Kahramanoğlu, R., Tiryaki, E. ve Canpolat, M. (2014). İlkokula yeni başlayan 60-66 ay grubu öğrencilerin okula hazır oluşları üzerine inceleme. K. Ü. Kastamonu Ĕ̆itim Dergisi, 23 (3), 1065-1080

Kartal S (2013). Türkiye'de ilkokula başlama yaşinin beş yaşa indirilmesinin eğitim politikalari açisindan değerlendirilmesi. Mülkiye Dergisi, 37(3), 201-214.

Kaya, M., Özel, Ö. Ö. ve Kaya, B. (2006) Malatya İl Merkezinde Farklı sosyoekonomik koşullardaki iki ilköğretim okulu öğrencilerinde ruhsal uyum taraması. Anadolu Psikiyatri Dergisi, 7(3), 157-161. 
Kazu, İ.Y. ve Eroğlu, M. (2012). Eğitim fakültesi öğretim elemanlarının 12 ylllık zorunlu eğitim sistemine yönelik görüşlerinin belirlenmesi . 2. Ulusal Eğitim Programları ve Öğretim Kongresi bildiriler içinde (s.50-52), 27-29 Eylül 2012 Bolu: Abant İzzet Baysal Üniversitesi.

Kerimoğlu, F. (2014). Farklı yaştaki çocuklarm oluşturduğu ilkokul 1. sımıflarda yaşanan sorunların belirlenmesi. Yayınlanmamış Yüksek Lisans Tezi, Ankara Üniversitesi, Eğitim Bilimleri Enstitüsü, Ankara.

Keskinkılıç, K. (2002). Ilkokuma yazma öğretimi. Ankara: Nobel Yayınları.

Koçyiğit, S. (2009). İlköğretim birinci sinıf öğretmenlerinin ve ebeveynlerin görüşleri ışığında okula hazır bulunuşluk olgusu ve okul öncesi eğitime ilişkin sonuçları.Yayınlanmamış Doktora Tezi. Selçuk Üniversitesi, Konya.

Koçyiğit, S. ve Saban, A. (2014). Birinci sınıf öğretmenlerinin ve ebeveynlerin görüşlerine göre okula hazır bulunuşluk, Kuramsal Egitimbilim Dergisi. 7(3), 322-341.

Kutluca, C. A. N. ve Yıldızbaş, F. (2014). Okul öncesi ve sınıf öğretmenlerinin 60- 72 aylık çocukların okula hazır bulunuşluklarına ilişkin görüşleri. Abant İzzetBaysal Üniversitesi Ĕğitim Fakültesi Dergisi. 14(1), 33-50.

Külekçi, E. (2013). 4+4+4 eğitim sistemi kapsamında birleştirilmiş sınıf uygulamasına ilişkin öğretmen görüşlerinin değerlendirilmesi. Ĕgitim ve ÖğretimAraştırmaları Dergisi, 2(2), 369-377.

Memişoğlu, S. P. ve İsmetoğlu, M. (2013). Zorunlu eğitimde 4+4+4 uygulamasına ilişkin okul yöneticilerinin görüşleri. Eğitim ve Öğretim Araştırmaları Dergisi, 2(2), 14-25.

Merter, F., Şekerci, H. ve Bozkurt, E. (2014). Aynı sınıfta öğrenim gören altmışaltı ve yetmiş iki aylık öğrencilerin yaşadığı sorunların öğretmen görüşlerine göre değerlendirilmesi, NWSA-Education Sciences, 9(2), 87-98. doi: 12739/NWSA.2014.9.2.1C0608

MEB, (2012). İlköğretim Kurumları Yönetmeliğinde Değişiklik Yapılmasina Dair Yönetmelik, Resmi Gazete, Sayı: 28360. 29 Mart 2018 tarihinde http://www.resmigazete.gov.tr/main.aspx?home=http://www.resmigazete.gov.tr./eskiler/2012/07/20120721.htm\&main=http://www.resmigazete.gov.tr/eskiler/2012/07/20120721.ht $\mathrm{ml}$ adresinden indirilmiştir. 
Ogelman, H.G., Seçer, Z., Gündoğan, A. ve Bademci, D. (2015). 68-72 aylık okul öncesine ve ilkokula devam eden çocukların okula uyum ve öğretmenleriyle ilişkilerinin karşılaştırılması, Ondokuz Mayıs Üniversitesi Eğitim Fakültesi Dergisi, 34(1), 1-17. doi:10.7822/omuefd-.34.1.1

Oktay, A. (2010). İlköğretime hazır oluş ve hazır oluşu etkileyen temel faktörler. A. Oktay, (Ed.), Ilköğretime hazırlık ve ilköğretim programlarl, içinde (s. 21-34).Ankara: Pegem Akademi.

Özenç, M. ve Çekirdekçi, S. (2013). İlkokul 1. sınıfa kaydolan okul öncesi dönem çağındaki öğrencilerin (60-69 ay) yaşadıkları sorunlara ilişkin öğretmen görüşleri. Abant İzet Baysal Üniversitesi Eğitim Fakültesi Dergisi, 13(2), 177-192.

Özkesemen, A. (2008). Okul öncesi eğitimi alan ve almayan 1. sını öğrencilerinin akademik başarılarının yeni müfredat programına göre değerlendirilmesi. Yüksek Lisans Tezi, Kafkas Üniversitesi, Sosyal Bilimler Enstitüsü, Kars.

Öztürk, E. ve Uysal, K. (2013).̇llkokul 1.sınıf öğrencilerinin okumayazma süreçlerinin takvim yaşı yönünden karşılaştırılması. International Periodical ForThe Languages, Literatureand History of Turkish orTurkic 8 (8), 1041-1054.

Patton, M. Q. (2014). Nitel araștırma ve değerlendirme yöntemleri. M. Bütün ve S. B. Demir (Çev. Edt.). Ankara: Pegem Akademi.

Pedder, D. (2006). Are small classes better? Understanding relationships between class-size, classroom practices and pupils' learning. $O x$ ford Review of Education, 32 (2), 213-234

Peker, Ü. D. (2013). Sınıf öğretmenlerinin 4+4+4 uygulamasına yönelik görüşleri. Eğitim ve Öğretim Araştırmaları Dergisi, 2(4), 324-337.

Polat, O., Kurtuluş, K. E., Sohtorıkoglu, N. Ş., Ozkabak, Y. T. ve Unsal, F. O. (2014). The comparision of 54-66 months old children's readiness for primary school during preschool period and their adaptation to primary school, International Journal on New Trends in Education and Their Implications. 5(1), 169 -182.

Sağlam, H.İ. ve Besen, T. (2015 ). Sınıf öğretmenlerinin 60-66 aylık çocukların ilkokula başlamasıyla ilgili görüşlerinin incelenmesi, International Online Journal ofEducational Sciences, 7(2), 167 -179, doi:10.15345/iojes.2015.02.019 
Selimhocaoğlu, A. (2009). Farklı sosyo-ekonomik düzeylerdeki ilköğretim okullarında okuyan öğrencilerin anne-babalarının değerlendirmesine göre uyum sorunları (kırşehir il örneği). Türk Psikolojik Danışma ve Rehberlik Dergisi, 4(32), 32-42

Senemoğlu, N. (2012). Gelişim, Öğrenme ve Öğretim, (21. Bsm). Ankara: Pegem Akademi.

Seven, S. (2011). Okula uyum öğretmen değerlendirmesi ölçeği'nin geliştirilmesi. Türk Ĕ̆itim Bilimleri Dergisi, 9(1), 29-42

Sevinç, M. (2005). Erken çocuklukta gelişim ve eğitimde yeni yaklaşımlar. İstanbul: Morpa

Snow, K. L. (2006). Measuring school readiness: Conceptual and practical considerations. Early Education and Development, 17, 7-41.

Şahin, A.E. and Güzel, C.I. (2018). Investigation of school readiness and academic development of elementary students firstly enrolled at school with '4+4+4 education regulation' in Turkey. Educational Policy Analysis and Strategic Research, 13(2), 104-127. doi: 10.29329/epasr.2018.143.6

Şentürk, C. (2016). Takvim yaşı olarak ilkokul birinci sınıf eğitimine erken başlayan çocuklarda karşılaşılan güçlüklere ilişkin öğretmen görüşleri. Journal of European Education, 6(3), 2146-2674.

Teke, H. (2010). Ana sınıfı öğretim programının ilköğretim 1. kademe 1. sinıf öğrencilerinin hazırbulunuşluk düzeylerine etkisinin öğretmen görüşlerine göre incelenmesi. Yüksek Lisans Tezi, Selçuk Üniversitesi, Konya.

Tutal, Ö. Ve Oral, B. (2015). İlk okuma-yazma öğrenmede okula başlama yaşının okuma-yazma başarısına etkisi.Dicle Üniversitesi Ziya Gökalp Ĕ̆itim Fakültesi Dergisi, 24, 96-121.

TTB. (2012). Çocukların gelişim süreçleri ve okula başlama. Ankara: Türk Tabipleri Birliği Yayınları.

Uzun, E. M. ve Alat, K. (2014). İlkokul birinci sınıf öğretmenlerinin 4+4+4 eğitim sistemi ve bu sistem sonrasında ilkokula başlayan öğrencilerin hazırbulunuşlıkları hakkındaki görüşleri. Abant İzzet Baysal Üniversitesi Ĕ̆itim Fakültesi Dergisi, 14(2), 15-44.

Ülkü, B. Ü. (2007). Anasınıfı ve ilköğretim 1. sınıfa devam eden çocukların velileri ve öğretmenlerinin, çocukların okul olgunluğu hakkındaki 
görüşlerinin incelenmesi. Yayımlanmamış Yüksek Lisans Tezi, Çukurova Üniversitesi, Adana.

Ünver, G. B., Dikbayır, A. ve Yurdakul, B. (2015). Kesintili zorunlu eğitim ilkokul birinci sınıfuygulamalarının incelenmesi. K. $\ddot{U}$. Kastamonu Ĕ̆itim Dergisi 23 (4), 1647-1664.

Yangin, B. (2009). The relationship between readiness and reading and writing performances, Hacettepe Üniversitesi Eğitim Fakültesi Dergisi, 36, 316-326.

Yavuzer, H. (2012). Çocuk psikolojisi. İstanbul: Remzi Kitabevi.

Yıldırım, A. ve Şimşek, H. (2013). Sosyal bilimlerde nitel araștırma yöntemleri (9. Baskı). Ankara: Seçkin Yayıncilık

Yılmaz, E. ve Dikici, S. A. (2008). İlköğretim Birinci Sınıfa Devam Eden Çocukların İlk Okuma Yazmaya Geçiş Sürelerinin Okul Öncesi Eğitim Alma Durumuna Göre İncelenmesi. Çă̆daş Eğitim. 349, 30-36.

Yılmaz, N., Taşçı, G. ve Fidan, M. (2013). İlkokul Birinci Sınıf Öğretmenlerinin 60-66 Aylık Öğrencilerine İlişkin Görüşleri, XII. Ulusal Simı Öğretmenliği Ĕ̆itimi Sempozyumu bildiriler içinde (s.310-314). 23- 25 Mayıs 2013, Aydın.

Yoleri, S. ve Tanış, H.M. (2014). İlkokul birinci sınıf öğrencilerinin okula uyum düzeylerini etkileyen değişkenlerin incelenmesi. Karabük Üniversitesi Sosyal Bilimler Dergisi, 4(2), 130-141.

Yörükoğlu, A. (2010). Çocuk ruh sağhı̆̆ı, çocuğun kişilik gelişimi eğitimi ve ruhsal sorunları (30.bsm). İstanbul: Özgür Yayınları.

6287 Sayılı İlköğretim ve Eğitim Kanunu ile Bazı Kanunlarda Değişiklik Yapılmasına Dair Kanun. (2012). Resmi Gazete, 28261, 11 Nisan 2012.

\section{Kaynakça Bilgisi / Citation Information}

Özdemir, A. ve Battal, Ş. (2019). İlkokula erken yaşta başlayan öğrencilerin okula uyum süreci ve akademik başarı bağlamında yaşadıkları sorunlar. OPUS-Uluslararası Toplum Araştırmaları Dergisi, 11(18), 1633-1683. DOI: 10.26466/opus.529169 